\title{
Soil evolution and origin of landscape in a late Quaternary tectonically mobile setting: The Po Plain-Northern Apennines border in Lombardy (Italy)
}

\author{
Chiara Zuffetti ${ }^{*}$, Luca Trombino, Irene Zembo, Riccardo Bersezio \\ Dipartimento di Scienze della Terra, Università degli Studi di Milano, via L. Mangiagalli 34, 20133 I-Milano, Italy
}

Keywords:

Loess

Northern Apennines Paleosols

Po Basin Quaternary Tectonics

\section{ABSTRACT}

The interactions among Quaternary (paleo-) soil-forming, erosion, re-deposition and geomorphic processes at the origin of the present-day landscape are discussed at three isolated tectonic reliefs of the Southern Po Foredeep Basin of Lombardy (San Colombano, Casalpusterlengo and Zorlesco reliefs, Italy). These sites offer the possibility to combine different scales of geopedological, geomorphological, stratigraphic and structural observations, to unravel the contribution of climate and tectonics to the Quaternary geological evolution and to the origin of the landscape.

Field surveys, laboratory analyses and soil micromorphology were used to characterize the Late Quaternary pedogenic processes acting on different (paleo)surfaces, in combination with the detailed study of seven selected soil profiles. Pedo-stratigraphic correlations revealed that two alluvial/loess-paleosol sequences, which originated from the Late Pleistocene to Holocene glacial/interglacial fluctuations, are differently preserved throughout the present-day hill landscape. In situ paleosols allowed to localize the paleo-topographic surfaces of geomorphic, tectonic and sedimentary stabilization; redeposited paleosols, occurring systematically close to the main faults and/or at the erosional bottom of paleo-valleys, allowed to mark the stages of tectonic instability. The integrated approach contributed to unravel the composite nature and rank of the stratigraphic boundaries.

Polycyclic loess-soil aggradation characterized the stable paleo-highs, uplifted during different phases of active thrusting of the northernmost Emilian arcs of the Apennine, while valley incision, fluvial terracing, soil truncation and redeposition occurred in the intervening structural lows. In the San Colombano hill area, Late Pleistocene transtensional faulting induced changes of the drainage network and enhanced redeposition of paleosols in colluvial wedges on the hangingwalls, along the fault scarps. LGM loess was preserved above different dissected remnants of the paleo-topography composing the hilltops. These new constraints permit to refine the Late Quaternary tectono-depositional history and landscape evolution at the southern margin of the Po Basin.
\end{abstract}

\section{Introduction}

In a Quaternary alluvial foredeep basin, like the Po Basin, the interaction between tectonics and climate resulted in mobile depositional and morphological settings and determined a great complexity of geomorphological and stratigraphic features (Ghielmi et al., 2013; Ori, 1993). In such settings the geological surfaces assume the significance of stratigraphic boundaries (aggradational, i.e. conformable vs. erosional, i.e. unconformable) and of morphological surfaces (i.e. stable surfaces where mostly pedogenesis occurs; Blum and Price, 1998; Bridge, 2003); their geopedological characterization might help to differentiate the sites where only weathering occurred after landform stabilization, from those where tectonic instability, erosion and/or sediment aggradation were the dominant processes. Ranking of these surfaces, i.e. their "high" or "low" position in the stratigraphic hierarchy (Aigner et al., 1999; Heinz and Aigner, 2003; Miall, 1996; Reading, 1996; Weber, 1986), contributes to relate the tectonic, depositional and pedogenetic processes to the regional tectono-sedimentary and climatic history. Paleosols (Costantini, 2017 and references therein) were used as paleoclimatic and paleoenvironmental markers of exposed and buried paleosurfaces in subsiding alluvial basins (Amorosi et al., 2017; Bracone et al., 2012; Bruno et al., 2017; Mc Carthy and Plint, 2003; Morelli et al., 2017), and/or as chronological constraints of the morpho-tectonic changes that affected a mobile depositional setting (e.g. Frigerio et al., 2017; Srivastava et al., 2009; Varga et al., 2011; Zembo et al., 2012; Zerboni et al., 2014). These studies put into evidence how the interplay between tectonic displacement and erosional events deeply controls the distribution and preservation of paleosols. For this reason, the integration of data from geopedology, geomorphology, stratigraphy and tectonics is needed to describe complex morpho-structural settings, and to distinguish between climatic and tectonic influences on the pedostratigraphic architecture on different time scales. In other words, pedological and paleopedological studies help to constrain the deposition-deformation history at the origin of the present-day landscapes.

We applied such an integrated approach to the southern sector of the Central Po Plain of Lombardy (Italy). The area belongs to the Quaternary Po Basin, which represents the foredeep of the Northern Apennines, pinched in between this $\mathrm{N}$-wards verging orogen and the Alpine chain to the North. Quaternary Apennine faulting and folding affected the gently SE-wards sloping, Alpine-sourced alluvial sediments, resulting in the origin of some tectonic reliefs which at present stand isolated in the centre of the Po alluvial plain and close to both the Alpine and Apennine basin margins (Alfano and Mancuso, 1996; Anfossi et al., 1971; Ariati et al., 1988; Benedetti et al., 2003; Boni, 1967; Bresciani and Perotti, 2014; Burrato et al., 2003; Castiglioni and Pellegrini, 2001; Cremaschi, 1987; Desio, 1965; Livio et al., 2014; Pellegrini et al., 2003; Pieri and Groppi, 1981; Zuffetti et al., 2018; Fig. 1A). These uplifted landforms show typical loess-paleosol sequences at the top of the dissected and weathered Pleistocene glacio-fluvial sediments (Busacca and Cremaschi, 1998; Cremaschi, 1987; Cremaschi et al., 2015; Ferraro, 2009; Livio et al., 2012, 2009; Zerboni et al., 2014). Their pedo-stratigraphic history allows gaining important information on the paleoclimatic and tectonic changes that affected the Po Plain during the Pleistocene. Nevertheless, both the depositional and pedological history and the chronology of tectonic and erosional events are still under debate. Owing to the lack of age determinations, the chronology of the geo-pedological evolution of the tectonic landforms of the southern Po Plain has been mainly based on indirect evidences so far.

This paper focuses on three tectonic reliefs which are close to the southern Po Basin margin, at the Apennine side, that are the San Colombano, Casalpusterlengo and Zorlesco relic reliefs (Fig. 1). They provide comprehensive case-studies on how erosion/sedimentation processes, soil forming 
processes and tectonic mobility interact to shape a complex landscape. These reliefs hold a certain relevance because: i) different soils developed above alluvial-loess sediments both on the hills and the surrounding terraced plain (Cremaschi, 1987; Zuffetti et al., 2018 and references therein). However, the available geological maps (Anfossi et al., 1971; Boni, 1967; Pellegrini et al., 2003) and the pedological studies performed on the study area (ERSAL, 2013, 2001a, 2001b, 2000) have neither accounted for a detailed analysis of paleosols, nor they have been properly integrated into an evolutionary model of the structures during the Late Pleistocene; ii) the reliefs are located at the hinge belt between the Po Plain and the Northern Apennine chain, where the chronology of the Late Quaternary morpho-tectonic increments is still under debate (Benedetti et al., 2003; Burrato et al., 2012, 2003; Pellegrini et al., 2003). Recent studies on the San Colombano relief revealed that latest Quaternary faulting contributed to shape the geomorphology of the hill and that tectonic increments affected soil evolution and led to their displacement (Zuffetti et al., 2018). Hence, the issues we address in the present paper are: I) do superposed paleosols represent tectono-stratigraphic markers along the isolated reliefs of the southern Po Plain? II) how can the study of the pedo-sedimentary sequence at these sites contribute to unravel the imprints of climate cycles and tectonic increments, in order to refine the paleo-landscape evolution at the Po Plain-Apennine border? Our results are based on the integration of geopedological and sedimentological field mapping and descriptions with micromorphological observations, chemical and sedimentological analyses, and new age determinations on the Late Pleistocene alluvial stratigraphic units.

Some abbreviations recur in the following Paragraphs. In order to facilitate the reading, the complete list of abbreviations is disclosed here, in alphabetical order: AIR: active iron ratio; a.s.l.: above sea level; BHL: borehole; b.g.s.: below ground surface; CAS: Casalpusterlengo hill; CPS: Cascina Parina Synthem; cc: clay coating; $\mathrm{Fe}_{\mathrm{d}}$ : dithionite citrate bicarbonate extractable iron; $\mathrm{Fe}_{\mathrm{o}}$ : oxalate-soluble iron; $\mathrm{Fe}_{\mathrm{p}}$ : sodium pyrophosphate extractable iron; INS: Invernino Synthem; L1: Loess cover 1; L2: Loess cover 2; LGM: Last Glacial Maximum; MLS: Monteleone Synthem; MSa/b/c: Morphological surface a/b/c; pf: pedofeature; PML: Po Plain Main Level; POS: Po Synthem; Sn-m: Stratigraphic surface n (high rank)/n-m (low rank); SCn: morphological sector ' $n$ ' of the San Colombano hill, TER: morphological sector of the terraced plain, VIL: Villanterio Unit; ZOR: Zorlesco hill.

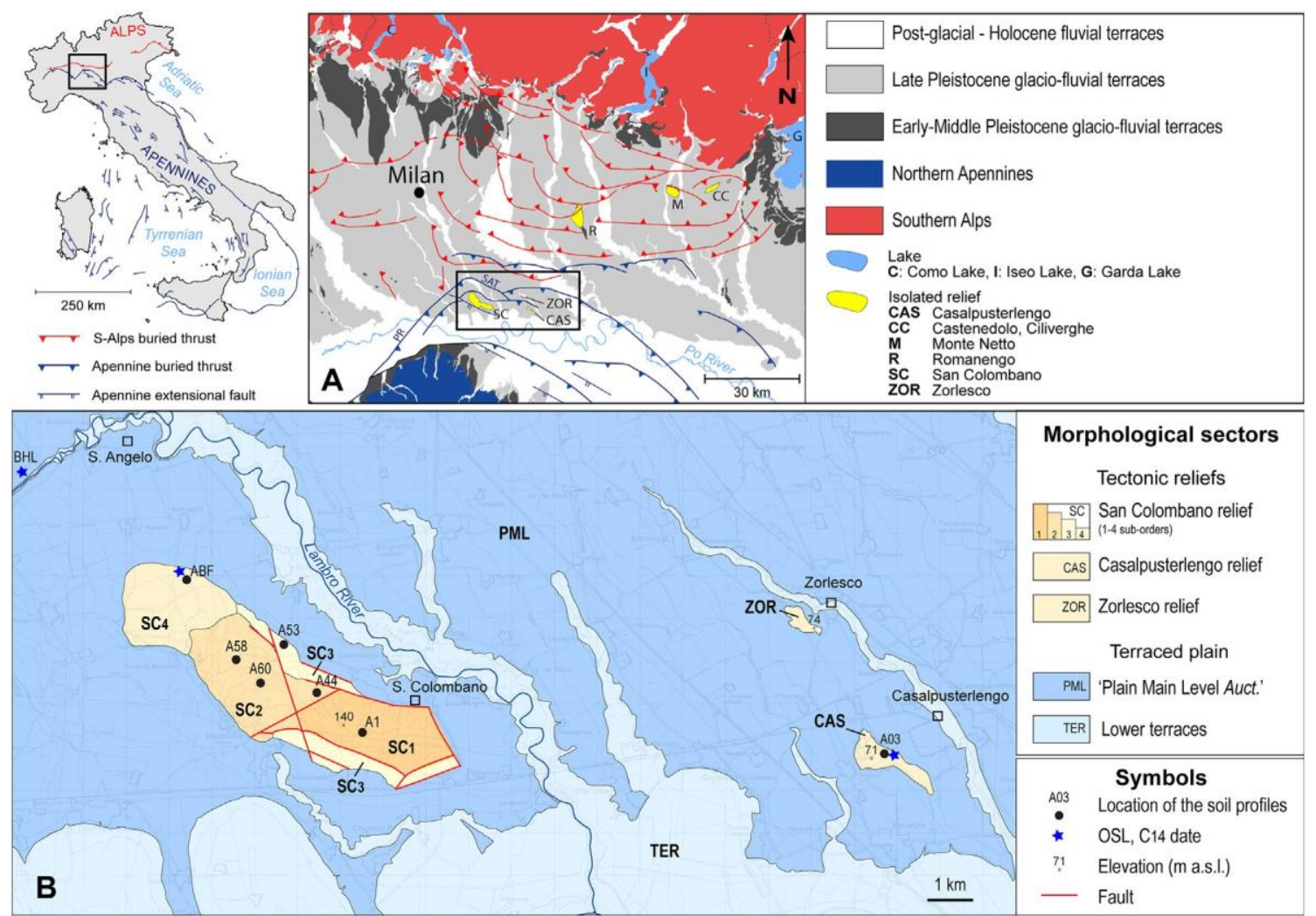

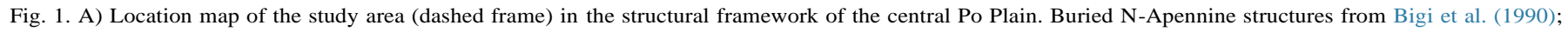

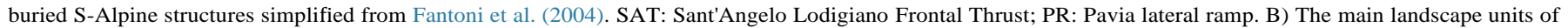
the study area (modified after Bersezio et al., 2010; Zuffetti et al., 2018). 


\section{Study area}

\subsection{Geological setting}

The Po Plain belongs to the widest foreland basin of Italy, shared by the converging South Alpine and Apennine chains. The main structural elements that characterize the basin (Fig. 1A) are the buried fronts of the south-verging Southern Alps, to the north, and the north- to northeast-verging Northern Apennines, to the south (Bigi et al., 1990; Fantoni et al., 2004; Pieri and Groppi, 1981). From the Late Miocene, the Po Basin evolved through successive tectonic phases resulting in an outward migration of the northern Apennine thrust and fold belt, that intersected the south-alpine one along a buried W-E extended belt in the Central Po Plain. Even if both the structural fronts are still active (D'Agostino et al., 2008; Devoti et al., 2011), the Quaternary evolution at the Po Basin-Apennine fringe is mainly controlled by the northernmost Apennine structures, for which on-going thrusting (Boccaletti et al., 2011; Burrato et al., 2003; Maesano et al., 2015; Maesano and D'Ambrogi, 2016; Scrocca et al., 2007; Toscani et al., 2006) and Late Pleistocene extension (Argnani et al., 2003; Bertotti et al., 1997) have been proposed.

The Quaternary succession of the Po Plain of Lombardy (Fig. 1A) belongs to a regional, Alpine-sourced regressive sequence developed above the Miocene and Pliocene deep to shallow marine units, starting with Lower-Middle Pleistocene transitional sequences and passing upwards to alternating coarse and fine-grained glacio-fluvial and alluvial units (Ghielmi et al., 2013; Regione Lombardia and Eni Divisione Agip, 2001). These are involved, to the South, into Apennine thrust-related folds and faults. In this sector, the San Colombano, Casalpusterlengo and Zorlesco reliefs emerge (Fig. 1), representing the topographic expressions of the most external buried arcs of the northern Apennine thrusts (Alfano and Mancuso, 1996; Ariati et al., 1988; Benedetti et al., 2003; Bresciani and Perotti, 2014; Burrato et al., 2003; Cremaschi, 1987; Desio, 1965; Pellegrini et al., 2003).

Their evolution has been controlled by northward thrust folding and progressive uplift since the Late Miocene (Boni et al., 1981; Ghielmi et al., 2013 and references therein). Since the Pleistocene, the San Colombano structure has been involved in uplift and dextral wrenching, driven by the Nwards propagation of the S. Angelo Lodigiano frontal thrust along the Pavia lateral ramp (SAT and PR, respectively, Fig. 1; Bigi et al., 1990; Benedetti et al., 2003) and dissected by repetitive faulting events up to the Latest Pleistocene (Zuffetti et al., 2018). To the East, the S. Angelo thrust intersects the WNW-ESE oriented Mio-Pliocene structures buried below the Casalpusterlengo and Zorlesco reliefs (Desio, 1965; Cremaschi, 1987; Anfossi et al., 1971), where recent stratigraphic studies documented active folding and uplift during the Middle-Late Pleistocene (Bersezio et al., 2016, 2010).

\subsection{Climate and paleoclimate}

At present the Lower Po Plain has a sub-humid, Mediterranean subcontinental climate, with average annual temperatures between $12{ }^{\circ} \mathrm{C}$ and $15{ }^{\circ} \mathrm{C}$ and a mean annual rainfall of 670-1200 mm (ARPA Lombardia, 2016). The present-day soil-temperature regime of the Lower Po Plain is mesic (according to USDA, 1999), the soil-moisture regime is ustic (Costantini et al., 2013). Climatic conditions during Late Quaternary glacial-interglacial cycles were different from the present-day. The Po Plain was an arid steppe since Marine Isotope Stage (MIS; Martinson et al., 1987; Shackleton, 1987) 4, after a warm interglacial phase in the early MIS 5; aridity and climate cooling progressively increased until MIS 2; the last main glacial expansion to the south of the Alps was punctuated by brief interstadials that permitted a polycyclic pedogenesis (Amorosi et al., 2008, 2004; Cremaschi, 1987; Cremaschi et al., 2015; Pini et al., 2009; Zerboni et al., 2014). Humid environmental conditions and continuous vegetal covers characterized the Early and Middle Holocene (Amorosi et al., 2004; Ravazzi et al., 2012; Wick, 1996).

\section{Materials and methods}

The detailed study of the San Colombano relief area was accompanied by the reassessment of the soil characterization at the Casalpusterlengo relic relief site after the papers by Cremaschi, (1987), ERSAL (2002) and Panzeri et al. (2011). At both sites, detailed geological and geomorphological mapping have been carried out and the results are presented in Zuffetti et al. $(2018,2017)$ for the San Colombano and briefly summarized in Bersezio et al. (2010) for the Casalpusterlengo area. Focus was on the geopedological characterization of the stratigraphic and morphological surfaces, which are the boundaries of the stratigraphic units and the preserved relicts of topographic surfaces, in order to better constrain the stratigraphic relationships along the different morphological sectors of the area. For this reason, the classical geological, sedimentological and geomorphological field surveys were accompanied by: i) a distributed homogeneous mapping of surface soil textures and colours (Munsell®, 1994) both on the reliefs and for each agrarian parcel of the surrounding plain (Zuffetti et al., 2018); ii) a detailed geopedological description of seven soil profiles (Fig. 1B), which were selected as representative of the soil types associated with the hill landforms and as reference sections for the features of the mapped geological boundaries. Field soil description followed Cremaschi and Rodolfi (1991) and WRB (2015) procedure. Horizon nomenclature followed the naming convention of FAO (2006). For each described horizon, 0,5 to $2 \mathrm{~kg}$ of soil material were sampled for laboratory analyses (Cremaschi and Rodolfi, 1991; Mc Rae, 1991) and undisturbed samples were collected using Kubiëna boxes (Kubiëna, 1953), to obtain thin sections for micromorphological analyses.

Grain size distribution analyses (Gale and Hoare, 1991; Ministero per le Politiche Agricole, 1999) were performed after removing organics by hydrogen peroxide treatment. Sediments were wet sieved $(2000-63 \mu \mathrm{m})$ and the $<63 \mu \mathrm{m}$ fraction was determined by Casagrande's aerometer. Organic matter and $\mathrm{pH}$ (1:2,5 soil:water) (Ministero per le Politiche Agricole, 1999; Walkley and Black, 1934) were also measured. Iron content was determined for three selected profiles at the San Colombano hill site (A1, A44, A53; Fig. 1B), as representative for the pedo-stratigraphic history of the related geomorphological sectors ( $\mathrm{SC} 1, \mathrm{SC} 2$, SC3 sectors, respectively; Fig. 1B). Oxalate-soluble iron ( $\mathrm{Fe}_{\mathrm{o}}$ ) was estimated using the Schwertmann (1964) method. Dithionite citrate bicarbonate $\left(\mathrm{Fe}_{\mathrm{d}}\right)$ and sodium pyrophosphate $\left(\mathrm{Fe}_{\mathrm{p}}\right)$ extractable irons were determined in compliance with the office Italian methods (Ministero delle Politiche Agricole e Forestali, 2000). Consequently, active iron ratio (AIR; Rhodes and Sutton, 1978) was calculated as $\mathrm{Fe}_{\mathrm{o}} / \mathrm{Fe}_{\mathrm{d}}$. On the basis of the colour of the surveyed soil horizons, a Redness Index (RI) was rated with Munsell Charts using the method of Buntley 
and Westin (1965) and modified by Cordova (2000). AIR and RI were used to discuss the soil polygenesis (Lucke and Sprafke, 2015), and to estimate the soil aging. Soil thin sections of $5 \times 8 \mathrm{~cm}$ size,

20 to $30 \mu \mathrm{m}$ thickness, were prepared on covered glass slides from undisturbed oriented samples following the procedure of Murphy (1986). Optical polarizing microscope observations were carried out according to Stoops (2003), taking notions and concepts of Brewer (1964) and Bullock et al. (1985), and interpreted according to Stoops et al. (2010). The interpretation of soil evolution was mainly based on the integration between field and micromorphological observations, physical and chemical laboratory analyses. The chronostratigraphic framework relies on two new Accelerator Mass Spectrometry (AMS) radiocarbon age determinations, combined to the radiocarbon and optically stimulated luminescence (OSL) ones from the previous works (Baio et al., 2004; Bersezio et al., 2004; Panzeri et al., 2011). Further age constraints came from the available archaeological findings documented in the San Colombano hill area (Pellegrini et al., 2003; Valle, 1984; new and recent findings) and contributed to refine the pedostratigraphic correlations of the stratigraphic units composing the 'Po Plain Main Level' morphological unit (Castiglioni and Pellegrini, 2001). Soils have been classified according to the WRB taxonomy (WRB IUSS Working Group, 2015). The new pedological dataset collected on the southern Po Plain, together with the outcomes of unpublished and available (ERSAL, 2013, 2001b) soil surveys carried out in the Po Plain of Lombardy during the previous years, were normalized, digitized and stored into a specific GIS-based Geodatabase, to allow comparison and correlation of all data.

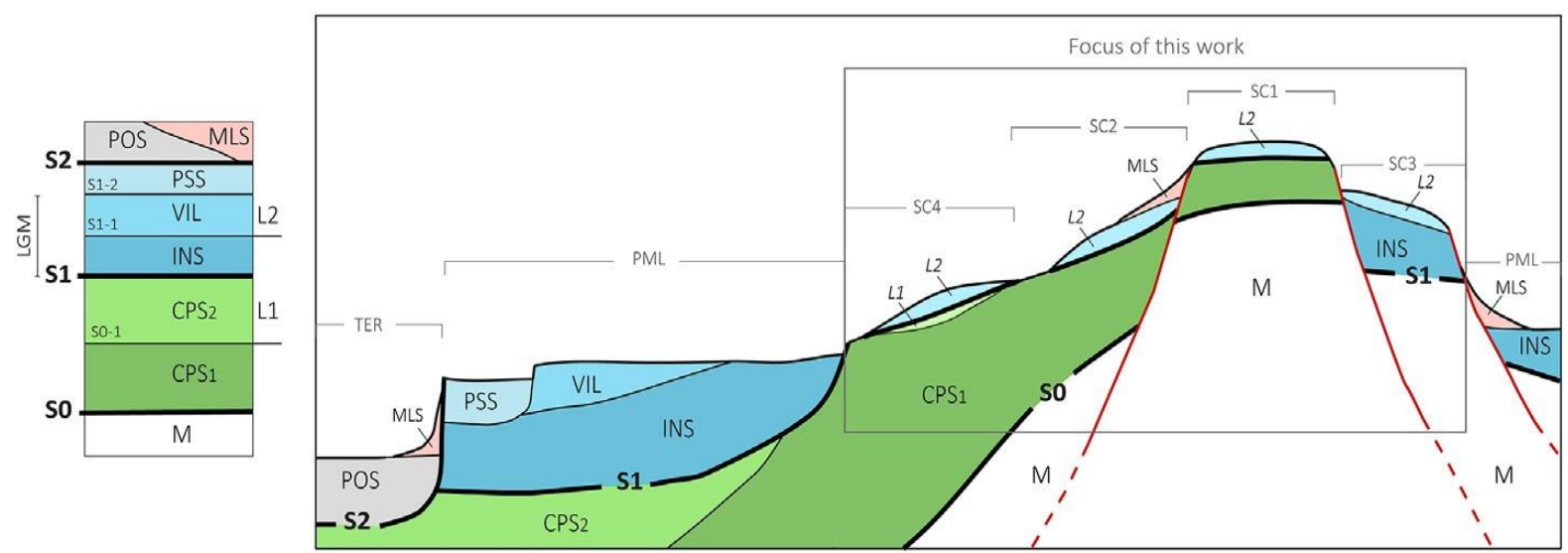

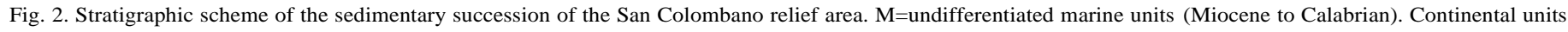

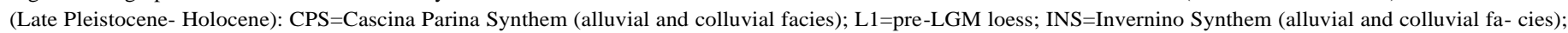

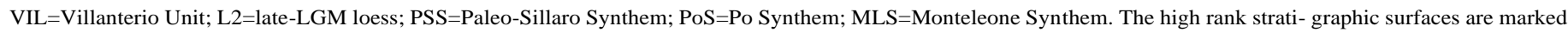

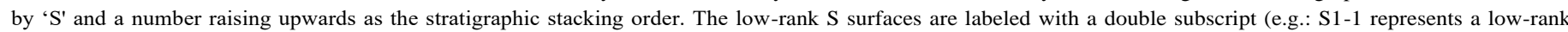

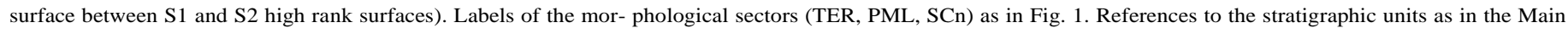
text - Paragraph 4

\section{Results}

In the studied area, the isolated reliefs preserve evidence of Quaternary climate changes and syn- to post-depositional tectonics. Based on the observed tectonic-induced morphologies, several morphotectonic sectors have been identified (Zuffetti et al., 2018; Fig. 1B), where different pedostratigraphic features and soil profiles are preserved. Hence, in this section we firstly introduce the morpho-tectonic sectors and the basic stratigraphy of the area, then we describe the geopedological features of the morpho-tectonic sectors by presenting the most representative soil profiles for each. Focus is on the (paleo)pedological features in the San Colombano hill area, compared to those of the Casalpusterlengo and Zorlesco reliefs.

\subsection{Geomorphology}

The San Colombano, Casalpusterlengo and Zorlesco tectonic reliefs interrupt the major regional, SE-wards low gradient slope of the southern Po Plain Main Level (PML; Castiglioni and Pellegrini, 2001) that is cut by different orders of terraced surfaces (TER sectors, Fig. 1B) bounded by 5-15 $\mathrm{m}$ high escarpments. The San Colombano hill is characterized by i) a flat top surface between 140 and $146 \mathrm{~m}$ a.s.1., ii) straight steep fault-related slopes to the north, east and south, and iii) gentle slopes westwards, progressively linked to the PML (about $70 \mathrm{~m}$ a.s.1. close to the hill area). These geomorphic features have been interpreted as indicators of latest Pleistocene uplift and faulting (Zuffetti et al., 2018). The morphological sectors of the hill correspond to fault blocks. The most elevated and the intermediate sector (SC1 and SC2, respectively; Fig. 1B) are two adjacent fault blocks bounded by N150E and N60E-directed conjugate faults, while their northern and southern slopes develop from N110E-directed steep faults, which downthrow the hangingwalls away from the hill. The southern limb of SC2 sector is carved by the Late Pleistocene terrace of a large fluvial bend, corresponding to an abandoned meander of the paleo-Po River. The sector SC3 (Fig. 1B) comprises the northernmost and southernmost fault blocks, bounded by the mentioned N110E faults and resting in between SC1-SC2 and the PML. The SC4 morphological sector corresponds to the gradual link between the NW termination of the SC hill and the PML, rising at most $20 \mathrm{~m}$ above it; it is bounded to the south by the mentioned bend of the paleo-Po trace. The Casalpusterlengo and Zorlesco smooth relic reliefs (CAS and ZOR sectors respectively, Fig. 1B) rise about 5 to $10 \mathrm{~m}$ above the surrounding PML (which is at about $62 \mathrm{~m}$ a.s.l. in the Casalpusterlengo area) without exposed fault boundaries. The present-day irregular morphology 
of CAS and ZOR sectors is the result of Latest Pleistocene-Holocene fluvial incision and intense historical quarrying activities on the Pleistocene sediments and uppermost soils.

\subsection{Quaternary stratigraphy}

The Quaternary stratigraphy of the study area developed during syn- depositional folding, uplift and faulting and was lately affected by postdepositional tectonics (Zuffetti et al., 2018, with references therein). As a consequence, a long hiatus separates the Early Pleistocene marine substratum from the overlying Late Pleistocene regressive alluvial sediments in the exposed succession. This stratigraphy was then eroded, displaced and redistributed through the mentioned morphological sectors. In the description that follows, the high rank stratigraphic surfaces are marked by the letter ' $S$ ' and a number raising upwards as the stratigraphic stacking order (Fig. 2). The low-rank S surfaces are labeled with a double subscript (e.g.: $S_{1-1}$ represents a low-rank surface between S1 and S2 high rank surfaces).

\subsubsection{Pre-Last Glacial Maximum (LGM) units (Late Pleistocene)}

In the San Colombano outcrops, the Calabrian marine transgressive deposits ('San Colombano Formation'; Anfossi et al., 1971; Boni, 1967) unconformably overlay the folded and truncated deep-marine Miocene units. The composite high-rank stratigraphic surface S0 ('Middle-Late Pleistocene Unconformity', Zuffetti et al., 2018) truncates these marine units (M, Fig. 2) down to the Miocene substratum, owing to thrust-folding of the San Colombano anticline (Boni, 1967; Anfossi et al., 1971). At least two sequences of Late Pleistocene alluvial gravelly sands, correlative to glacio-fluvial, alpine-fed units cover S0 (CPS 1 and $\mathrm{CPS}_{2}$ sub-Synthems, Cascina Parina Synthem; Zuffetti et al., 2018). They are bounded by the lowrank stratigraphic surface $\mathrm{S}_{0-1}$. The Late Pleistocene age of the buried top of $\mathrm{CPS}_{2}$ is constrained by a date obtained in a borehole at $\mathrm{S}$. Angelo Lodigiano (Fig. 1), where wood fragments yielded a radiocarbon age of $25,180 \pm 150 \mathrm{yr} \mathrm{BP}$, corresponding to $27,648-26,884$ cal BC (2 $\sigma$ confidence interval 95.4\%, OxCal 3.10; Reimer et al., 2013; $30 \mathrm{~m}$ b.g.s.). $\mathrm{CPS}_{1}$ and $\mathrm{CPS}_{2}$ sediments are mostly composed of intrusive and high grade metamorphic lithoclasts with few sedimentary grains. The Synthem is uplifted at the highest elevation of the San Colombano hill along the fault block SC1, where CPS is truncated down to the minimum thickness of about $6 \mathrm{~m}$. In contrast, CPS exceeds $15 \mathrm{~m}$ at the sectors lowered by faulting (SC2, SC3 and SC4).

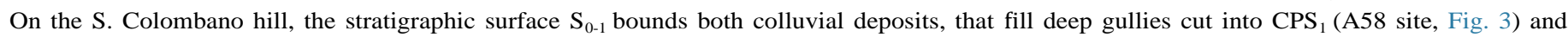
weathered loess deposits (L1 unit) that locally overlay the alluvial $\mathrm{CPS}_{1}$ (ABF site). L1 is only preserved in the morphological sector SC4 where an OSL date of $88,890 \pm 8800 \mathrm{kyr}$ BP was obtained by Panzeri et al. (2011) in the CPS1, just below the weathered loess profile.

The alluvial gravelly sands cropping out at Casalpusterlengo and Zorlesco (morphological sectors CAS and ZOR; 'Mindel', Anfossi et al., 1971; GU1, Bersezio et al., 2010), share facies and clastic petrography with the CPS and lay above an erosional surface which truncates an Early Pleistocene marine succession (Bersezio et al., 2010; Bini et al., 2016). At the same profile that we consider in the present work (A03; Fig. 1), Panzeri et al. (2011) obtained two OSL age determinations which bracket the Casale-Zorlesco gravelly sands between $107 \pm 13 \mathrm{kyr}$ BP and $67 \pm 6 \mathrm{kyr}$ BP. Based on these results we consider the Casale-Zorlesco succession a lateral equivalent to the Late Pleistocene CPS of the San Colombano area. The CAS- $\mathrm{S}_{0-1}$ surface lays in between the two mentioned OSL dates in A03 profile. Northwards, at the Zorlesco relief, it correlates to the erosional unconformity reported by Cremaschi (1987) between highly weathered alluvial sands and the lowermost weathered loess profile covered by a less weathered loess unit. Unfortunately, the Zorlesco succession has been entirely removed by quarrying. In literature, the surface soils above CPS have been defined as Chromic and Ferric Luvisols, Haplic arenosols in the San Colombano relief area (ERSAL, 2013, 2001a, 2000), while Haplic Luvisols (ERSAL, 2002) have been described over the correlative units at the Casalpusterlengo and Zorlesco reliefs. 


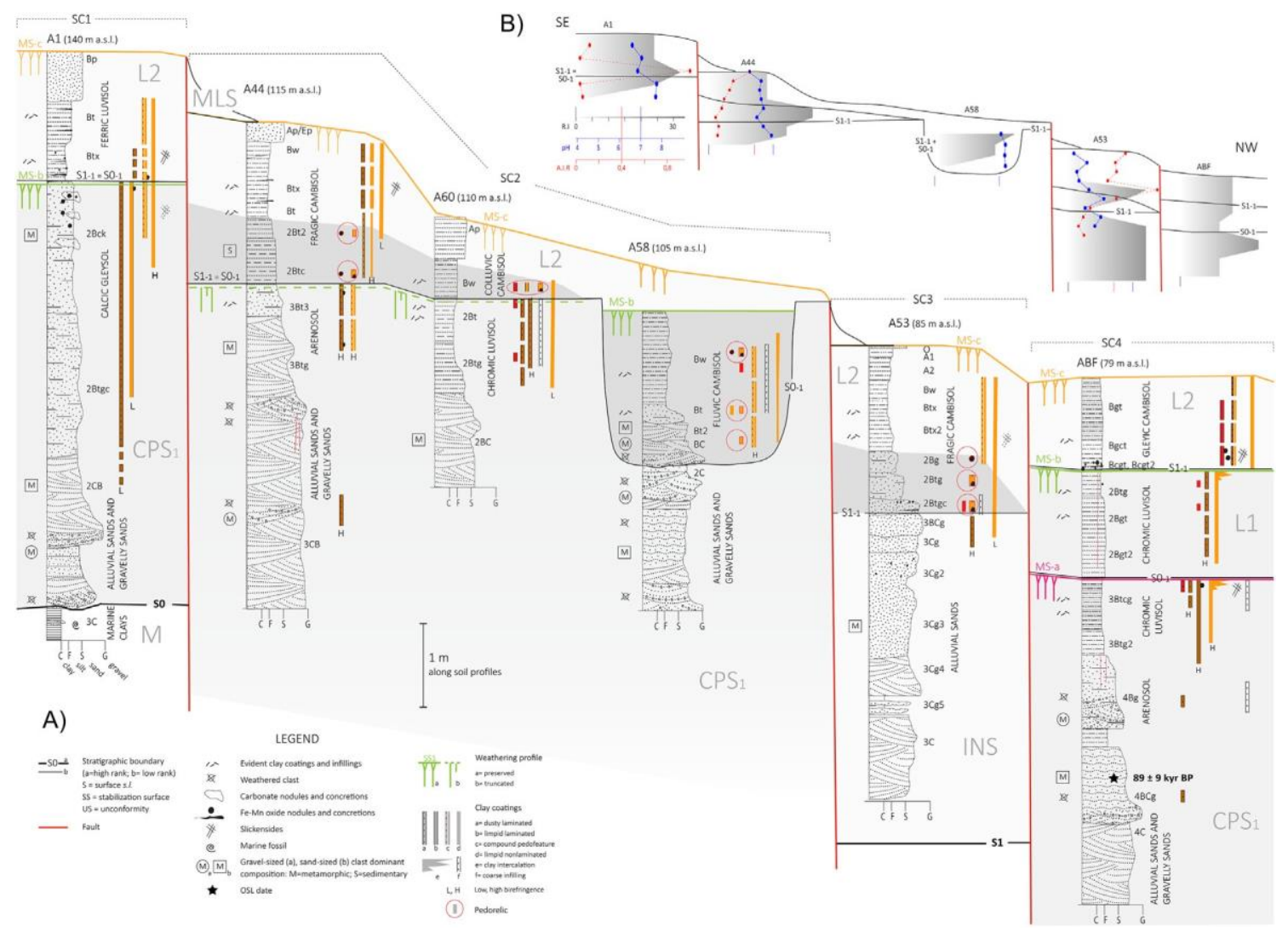

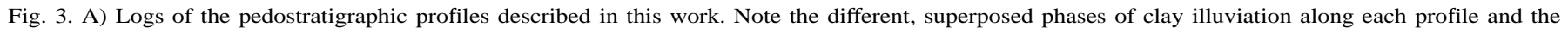

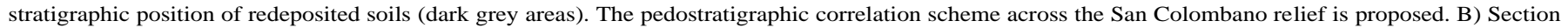

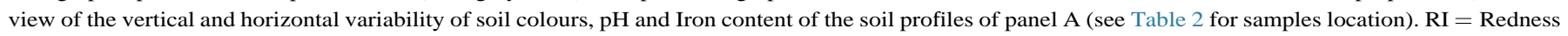

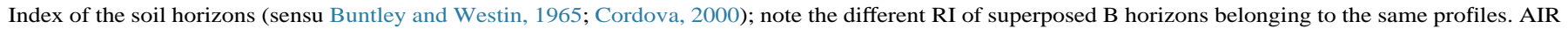
$=$ active iron ratio.

\subsubsection{LGM units (Latest Pleistocene)}

The recognition of Latest Pleistocene, LGM sediments in the San Colombano area is based on both stratigraphic correlation with the adjacent areas, where the LGM Cantù Synthem was reported and dated by Bersezio et al. (2004, 2010) just below the PML, and on new radiocarbon age determinations. At the already mentioned borehole W of S. Angelo (Fig. 1), woody particles from the top of the succession of stacked fining-upwards sand-mud sequences laying above CPS, yielded a radiocarbon age of 19,746 $\pm 150 \mathrm{yr}$ BP (22015-21,435 cal BC, $2 \sigma$ confidence interval $95.4 \%$, OxCal 3.10; Reimer et al., 2013) just 3 m b.g.s. All these Latest Pleistocene sediments lay above the composite erosional high rank stratigraphic surface S1 (Fig. 2), which truncates the CPS and older units down to the uplifted marine substratum.

The LGM sediments are alluvial sands and sandy gravels belonging to the Invernino Synthem (INS, Latest Pleistocene; Zuffetti et al., 2018; Fig. 2). INS consists of fining-upwards sequences, mostly containing sedimentary, volcanic and low-grade metamorphic lithoclasts. The alluvial deposits of INS shape wide parts of the PML terrace, where no loess cover is preserved. The INS succession is covered by the previously mentioned fining upwards sequences, which yielded the late LGM radiocarbon ages, north of the San Colombano hill. The low-rank stratigraphic surface $\mathrm{S}_{1-1}$ (Fig. 2) represents the lower boundary of the succession, above the INS top, that is denominated "Villanterio Unit" by following the local toponym (VIL in Fig. 2). This informal stratigraphic unit, typical of flood-plain and/or oxbow lake environment, is characterized by the abundance of silty and muddy layers which develop at the top of the sandy bedsets and contain a continental mollusc fauna, abundant calcareous nodules and carbonate-cemented layers.

On the San Colombano hill, S1 surface bounds the INS alluvial terrace that cuts the northern hillslope at the morphological sector SC3 (Figs. 2 , 3). The faulted remnants of this terrace rest in hanging position at the northern margin of the elevated blocks SC1 and SC2. This complex morphostratigraphic framework is the consequence of syn-depositional transtensional displacement along the conjugate fault system which dissects the San Colombano anticline (Zuffetti et al., 2018). Only the northern SC3 sector comprises alluvial INS sequences. These are covered by a mildly weathered loess (L2, Fig. 2), aggraded above the surface $\mathrm{S}_{1-1}$, while the southern part of SC3 totally lacks INS and L2 sediments. Differently, only L2 loess is present on the most elevated hill sectors SC1, SC2, and along part of the SC4 sector. Some wedges and lenses of colluvial deposits reworking fragments of reddish soils have been locally found above $\mathrm{S}_{1-1}$, below the L2 loess cover (sectors SC2 and SC3, Fig. 3). The mildly to poorly weathered, topmost loess sequence on top of the relic reliefs of Casalpusterlengo and Zorlesco, reported by Cremaschi (1987) as LGM loess, can be correlated to the L2 loess unit of the San Colombano hill. The surface soils developed above INS, L2 and correlative units have been defined as Chromic and Ferric Luvisols (hill sectors SC1-SC2), Haplic arenosols (north-eastern hill, SC3), Haplic Luvisols and Eutric Regosols in SC4 and PML sectors (ERSAL, 
2013, 2001a, 2000). Soil units mapped in correspondence to VIL have been mostly defined as Gley-luvic Calcisols, locally as Haplic Luvisols (ERSAL, 2013, 2001a).

\subsubsection{Latest and post-LGM units (Latest Pleistocene-Holocene)}

The PML surface is sculptured by the traces of an extinct meandering river network (Bersezio, 1986; Castiglioni and Pellegrini, 2001), poorly eroded within the Late Pleistocene units. The envelope of these erosion surfaces defines the low-rank erosion surface $S_{1-2}$ (Fig. 2), which bounds the meandering river sediments of the Paleo-Sillaro Synthem (PSS; Latest Pleistocene; Zuffetti et al., 2018). The age of PSS is constrained between the late LGM of the VIL and the post-glacial to Holocene age of the Po Synthem (see next indent). Gravels of PSS contain abundant volcanic rocks to the west of the hill, while limestone and arenite clasts get the most abundant eastwards. Thickness of PSS ranges from 1,5 to $5 \mathrm{~m}$ in the San Colombano area. The sediments of the previously mentioned paleo-Po meander, which bounds the SC2 and SC4 morphological sectors to the south of the San Colombano Hill belong to this unit. The PSS partly corresponds to the Post-glacial sediments described in the Casalpusterlengo area along NW-SE directed, abandoned river traces incised in the PML (Baio et al., 2004; Bersezio et al., 2004; Bersezio et al., 2010). A weak soil, < $1 \mathrm{~m}$ thick, is present at its top. The mapped PSS corresponds to the pedological map units classified as Haplic Luvisols (FAO, 2006) according to ERSAL (2013, 2001a, 2000).

The high rank, composite unconformity S2 (Fig. 2) deeply erodes the Pleistocene stratigraphy, including the PSS. It corresponds to the entrenchment of the post-glacial to Present river network by 10 to $20 \mathrm{~m}$ below the PML, depending on the location and on the size of the eroding river. S2 represents the lower boundary of the Po Synthem (PoS; Latest Pleistocene-Holocene; introduced by Amorosi et al., 2008; here we adopt the meaning given by Bini et al., 2014); it is a composite surface formed by multiple terrace scarps degrading towards the present-day river valleys (morphological sectors TER; Fig. 1B), that formed between 70 and $50 \mathrm{~m}$ a.s.l. in the study area. The poorly developed pedological units above the PoS are classified as Gleyic Luvisols, Gleyic Cambisols and Cambic Arenosols (ERSAL, 2013, 2001a, 2000).

\subsubsection{Colluvial deposits (Late Pleistocene-Holocene)}

Detailed sedimentological and geopedological analyses accompanying field surveys, allowed to recognize several buried and exposed colluvial and detrital deposits along the studied reliefs. These deposits drape the slopes of the morphological sectors, often relating to fault-scarps; within the fault-blocks they fill deep gullies cut into the CPS and INS units, recurrently recycling clasts from older soils, as it has been previously mentioned. Their peculiar position and lithology acquire a key-role in the interpretation of the Late Quaternary tectono-morphological history of the San Colombano hill, as will be discussed further on. Among the others, a typical exposed colluvial unit of the San Colombano hill morphological sectors is the Monteleone Synthem (MLS; Latest Pleistocene-Holocene; Zuffetti et al., 2018; Fig. 2). It develops above a composite disconformity and contains the polycyclic, most recent slope deposits of the relief. To the East, a correlation of MLS with the colluvial aprons on the slopes of CAS and ZOR morphological sectors (Bersezio et al., 2010) can be proposed.

\subsection{Geopedological features of the San Colombano relief: SC sectors}

The map of Munsell surface soil colours shows that they are heterogeneously distributed in the San Colombano relief area (Zuffetti et al., 2018): orange-red soil colours (7.5YR hues) characterize the topsoil on the CPS in the most elevated fault blocks of morphological sectors SC1 and SC2, and the buried soil on CPS in the downthrown sector SC4; mainly orange colours (10 YR hues) characterize the soil on top of the Latest Pleistocene-LGM INS both in the hill and PML morphological sectors; conversely, greyish to pale yellow colours (2.5 Y hues) designate the soil on top of the postLGM alluvial sediments of PSS and PoS in the PML and TER morphological sectors.

The most representative soil profiles to be investigated in detail have been selected for each morpho-tectonic sector, based on the following considerations: I) to investigate the most ancient and best preserved paleosols, the most complete succession of CPS has been considered (profile ABF, Figs. 1B, 3) in the downthrown SC4 morphological sector. In this area the preservation of stratigraphy permits to investigate the Late Pleistocene sequence of depositional, pedogenetic and erosional events corresponding to the CPS to PoS time span, hence across the $\mathrm{S}_{0-1}$ up to S2 stratigraphic boundaries and including loess L1 and L2 (Fig. 2). II) The profiles surveyed at the upper sectors (A1 in the uppermost fault-block SC1 and A44, A58 and $\mathrm{A} 60$ in the intermediate fault-block SC2; Fig. 3) permitted to focus on the top boundary of CPS and on the pedogenetic features preserved both below it and within the colluvial deposits and the L2 loess above it. III) Since only the northernmost SC3 sector comprises both alluvial deposits of INS and L2 loess on the San Colombano hill, we present the profile A53 to describe the pedogenic features of Latest Pleistocene-LGM units on the hill (Fig. 3). The results will be compared to the analyses on the pedological profiles

described at the Casalpusterlengo and Zorlesco reliefs, and to some correlative units mapped on the PML which are presented in the subsequent paragraph.

The essential field observations on the representative profiles are shown in Table 1, physicochemical analyses in Table 2 and Figs. 3 , 4, while micromorphological features are summarized in Table 3, respectively. The results for each profile are shown separately for every morphological sector; the interpretation derived from these data follows every profile description.

\subsubsection{Soils in SC4, the lowermost hill sector}

Profile ABF has been sampled at a quarry site in the NW end of SC4 (Fig. 1B), the lowermost sector of the hill above the PML. The first two metres below the ground surface consist of the colluvial and fan facies of Monteleone Synthem (Zuffetti et al., 2018) and have been removed for quarrying. The ABF section starts at $79 \mathrm{~m}$ a.s.1.; it is about $6 \mathrm{~m}$ thick and involves silts and clayey silts from top to $240 \mathrm{~cm}$, ascribed to L2 and L1 loess deposits (Figs. 3, 4 and 5A). The shallowest soil involves L2 loess (Fig. 4) above $\mathrm{S}_{1-1}$ surface and shows very few illuvial pedofeatures. In the Bgt to Bcgt2 horizons, illuvial pedofeatures comprise an older generation of laminated clay coatings ('cc' hereafter), rare in Bgt and strongly fragmented (orange to red, rounded, fragments of illuvial pedofeatures, i.e. papules sensu Brewer, 1964) in the groundmass of Bgct to Bcgt2; the second generation of brownish laminated coatings of dusty clay is associated to light orange, limpid microlaminated ones (Fig. 5C). In Bcgt2, these constitute a compound 
layer (Stoops, 2003) of silty to clayey coatings. Clay coatings are generally thin in the uppermost horizons. B-fabric turns from crystallitic (associated to channel microstructure, Bcgt) to striated (associated to blocky microstructure, Bcgt, Bcgt2; Fig. 5D). Subrounded, typic orthic and disorthic Fe-Mn nodules characterize the horizons Bcgt and Bcgt2. Nodules impregnate the first generation of laminated cc (Fig. 5D, E), and are fragmented and coated by the second generation of compound textural pedofeatures. A third generation of yellowish limpid, non-laminated cc is in continuity with the largest voids (Fig. 5C, E); frequent depletion pedofeatures (Stoops et al., 2010) involve the previously described ones.

Below $\mathrm{S}_{1-1}$, the horizon $2 \mathrm{Btg}$ is characterized by common illuvial papules of limpid, orange to red cc; laminated coatings of dusty brown clay with high birefringence are fragmented and deformed. These older generations of cc are overlain by orange, limpid microlaminated cc, that occur as thick sub-planar layers in the horizon $2 \mathrm{Btg}$ (Fig. $5 \mathrm{~F}$ ) and as thin, typic coatings in the $2 \mathrm{Bgt}$ and $2 \mathrm{Bgt}$. Scarce cc, silty texture and hydromorphic features in the form of diffuse, pale yellow mottles and thick hypocoatings around the biggest voids, are typical of these two horizons down to the surface $\mathrm{S}_{0}$ 1 .

Below $\mathrm{S}_{0-1}$, cc become dominant in the horizon 3Btcg; the matrix

colour is redder than in the overlying ones and the structure is blocky. At least three generations of cc have been distinguished. The oldest generation consists of brown-orange, laminated cc with high birefringence, commonly degenerated (Catt, 1989; Kemp, 1999; Stoops et al., 2010) or impregnated by Fe-Mn coatings and sub-rounded, typic and dense nodules. A second generation comprises orange, high birefringent, microlaminated cc, strongly dispersed in the groundmass (Fig. 5G) in the form of rounded papules or thick intercalations (Fedoroff and Courty, 2012); b-fabric changes from crystallitic to striated b-fabric. Silty coatings and stratified infillings (Fig. 5G) cross-cut all the previously described pedofeatures and are followed by a late evident depletion along voids. Fewer coatings and hydromorphism, and prevalent sandy texture are characteristic of horizons $3 \mathrm{Btg} 2$ towards 4BCg. The matrix colour is grey-brown, the nature and ordering of superposed cc are very similar, although less expressed, to the overlying $3 \mathrm{Btcg}$. The last generation of limpid cc often forms compound pedofeatures with Fe-Mn hypocoatings (Fig. 5H). The lowermost horizon of profile ABF is characterized by a bridged grain pellicular microstructure.

Interpretation

The profile shows a well-preserved compound sequence of (paleo-) soils, i.e. the markers of (buried) morphological surfaces of stabilization. The OSL dating of the basal CPS alluvial sediments and the occurrence of a strongly developed paleosol below $\mathrm{S}_{0-1}$ are coherent with Pleistocene interglacial conditions (Cremaschi, 1987). Here, the b-fabric of the topmost Bt horizon, marked by a re-orientation of the abundant clay intercalations, is probably the result of vertisolization processes. The absence of topsoil horizons on the alluvial CPS, the abrupt change in the most recent textural pedofeatures (Fig. 5G) and the essentially loessic nature of the overlying deposits (Fig. 4), testify that a weak truncation of the oldest soil occurred at $\mathrm{S}_{0-1}$, at the beginning of a climatic deterioration. Above it, the different generations of cc and hydromorphic pedofeatures testify that multiple stages of clay translocation occurred and show two maxima in the loess cover. The two most illuviated horizons (i.e. 2Btg and 3Btgc) show pervasive planar clay intercalations sensu Fedoroff and Courty (2012) that, together with the common observed hypocoatings and depletion pedofeatures, indicate that several alternating periods of waterlogging and rapid fluctuations took place in the profile after both stage of loess deposition. The base of L2 is marked by strong redoximorphic features ( $\mathrm{cm}$-sized nodules and mottles), that could have been enhanced by the fluctuation of the water-table in correspondence of the underlying, highly weathered loess L1. 


\begin{tabular}{|c|c|c|c|c|c|c|c|c|c|c|c|c|c|c|c|}
\hline $\mathrm{SCl}$ & A1 & 140 & $\begin{array}{l}\mathrm{Bp} \\
\mathrm{Bi} \\
\mathrm{Btx} \\
2 \mathrm{Bck} \\
2 \mathrm{BtgC} \\
2 \mathrm{CB} \\
\end{array}$ & $\begin{array}{l}\text { SF } \\
\text { cmFA-m } \\
\text { AF-m } \\
\text { mFAF-m } \\
\text { mISF-m } \\
\text { cfS }(F)-t \\
\end{array}$ & $\begin{array}{l}0-60 \\
60-110 \\
110-155 \\
155-310 \\
310-490 \\
490-680 \\
\end{array}$ & $\begin{array}{l}2.5 Y 660 \\
2.5 Y 6.6 \\
2.5 Y 6.8 \\
10 Y R 58 \\
10 Y 866 \\
2.5 Y 6.4 \\
\end{array}$ & $\begin{array}{l}24 \\
24 \\
24 \\
32 \\
24 \\
3 \\
\end{array}$ & $\begin{array}{l}3 \mathrm{mB} \cdot \mathrm{P} \\
3 \mathrm{mAB} \\
2 \mathrm{mSB} \\
- \\
- \\
\end{array}$ & $\begin{array}{r}+ \\
+ \\
++ \\
+ \\
\end{array}$ & $\begin{array}{c}++\mathrm{f} \\
++\mathrm{n} \\
++++n\end{array}$ & $\begin{array}{l}++ \\
+4\end{array}$ & $\mathrm{cH}$ & +++ & $\begin{array}{c}+ \\
++ \\
+\end{array}$ & $\begin{array}{l}\text { A i } \\
\text { Gs } \\
\text { nd } \\
\text { C i dipping NW } \\
\text { D s } \\
\text { Ds } \\
\end{array}$ \\
\hline \multirow[t]{19}{*}{ SC2 } & A44 & 115 & Ap:Ep & FfS & $0-20$ & & 18 & & & & & & & ++ & $\mathrm{Ai}$ \\
\hline & & & Bw & $c-1 T A-m$ & $20-40$ & 7.5YR 4.4 & 18 & $1 \mathrm{mSB}$ & & & $(+)$ & & & & A w dipping NW \\
\hline & & & Bix & $c-m F(A)-m$ & $40-70$ & 10YR6:6 & 18 & $2 \mathrm{mSB}$ & & ++1 & + & $\mathrm{c}++$ & & + & Gs \\
\hline & & & $\mathrm{Bt}$ & $c-f f A-m$ & $70-110$ & $10 Y R 66$ & 18 & $2 \mathrm{~m} \mathrm{SB}$ & & $+t f$ & + & $\mathrm{c}+\mathrm{H}$ & & + & As \\
\hline & & & $2 \mathrm{BI} 2$ & F fims-p 3005 & $110-140$ & 10YR5 6 & 32 & $1 \mathrm{mSB}$ & & & & & & + & A s dipping NW \\
\hline & & & $2 \mathrm{Btc}$ & $\mathrm{mPSF}-\mathrm{i}$ & $140-220$ & 7.5 YR5.6 & 32 & $2 \mathrm{mAB}$ & + & $+\mathrm{rn}$ & + & & & + & Gs \\
\hline & & & $3 \mathrm{Bt} 3$ & $\mathrm{~m} / \mathrm{m} \mathrm{mF}-\mathrm{I}$ & $220-240$ & 7.5YR5:6 & 24 & $2 \mathrm{mSB}$ & & $+f n$ & & & & & $\mathrm{Gs}$ \\
\hline & & & 3Btg & fSeF-1 & $240-260$ & $7.5 Y R 46$ & 24 & $1 \mathrm{mSB}$ & + & $(+)$ & & & & & Gis \\
\hline & & & $3 \mathrm{CB}$ & $\mathrm{m} / \mathrm{S}-\mathrm{I}$ & $260-300-$ & 10YR5 4 & 12 & & - & . & - & +++ & ++- & & nd \\
\hline & A60 & 110 & $A p$ & FIS & $0-50$ & $10 Y R 5.6$ & 18 & & & & & & & & As \\
\hline & & & BWW & $F-1$ & $50-94$ & 10YR5:6 & 4 & $3 \mathrm{AB}$ & & ++ & ++ & +++ & & H & G s dipping NW \\
\hline & & & $2 \mathrm{Bt}$ & FAfS-m & $94-150$ & 7.5 YR 4.6 & 32 & $3 \mathrm{AB}$ & +4 & $+4+$ & +4 & $+1+$ & & & Gs \\
\hline & & & $2 \mathrm{Big}$ & FfimSA-m & $150-210$ & 10YR5/8 & 18 & $3 \mathrm{SB}$ & & ++ & + & +++ & & + & nd \\
\hline & & & $2 \mathrm{BC}$ & $\mathrm{mS}(-1)$ & $210-320+$ & $10 Y R 5: 8$ & 21 &. & . & . & $(+)$ & +++ & & & nd \\
\hline & A58 & 102 & Bw & FAS-m & $0-110$ & $7.5 \mathrm{YR} 4.6$ & 24 & $3 \mathrm{mAB}$ & & $+4+1$ & $x+1+1$ & & & & Gs \\
\hline & & & $\mathrm{Bl}$ & $m I S(A) F(-1)$ & $110-130$ & $7.5 \mathrm{YR} 4.6$ & 18 & $2 \mathrm{mAB}$ & & + & ++ & & +1+1+ & & As \\
\hline & & & $\mathrm{Bt} 2$ & $\mathrm{mtS}(\mathrm{GA})-\mathrm{t}$ & $130-160$ & 7.5 YR5.6 & 18 & $2 \mathrm{mAB}$ & & + & + & & $++1++$ & & $\mathrm{Ai}$ \\
\hline & & & BC & $\mathrm{fG}-\mathrm{mSG}-\mathrm{t}$ & $160-180$ & $10 Y R+6$ & 4 & $2 \mathrm{fSB}-\mathrm{P}$ & & $+1+$ & H & & Hil & & $\mathrm{Ai}$ \\
\hline & & & $2 \mathrm{C}$ & $\mathrm{meSG}-\mathrm{t}$ & $180-350-$ & 10YR 5.6 & 4 & $\mathrm{ImG}$ & + & . & . & & $++4+5$ & & nd \\
\hline \multirow[t]{16}{*}{ SC3 } & A53 & 85 & 0 & fSF-m & $0-3$ & & & $1 \mathrm{fG}$ & $=$ & & & & & & $\Delta \mathrm{i}$ \\
\hline & & & Al & $\mathrm{F} F \mathrm{~F}-\mathrm{m}$ & $3-13$ & I0YR5.6 & 4 & $1 \mathrm{mG}$ & & & & $v e+4+$ & & & As \\
\hline & & & $\mathrm{A}_{2}$ & FFSA-m & $13-40$ & $10 Y R 56$ & 4 & $2 \mathrm{mG}$ & & & & ve $+4+$ & & & $\mathrm{Cs}_{\mathrm{s}}$ \\
\hline & & & Bw & $\mathrm{FA}-\mathrm{m}$ & $40-68$ & 10YR5:8 & 4 & $1 \mathrm{cAB}$ & - & $(+)$ & - & $\mathrm{c}+\mathrm{H}$ & & & As \\
\hline & & & Bix & $\mathrm{AF}-\mathrm{m}$ & $68-85$ & $10 Y R 5: 8$ & 4 & $2 \mathrm{cAB}$ & & $+f$ & $(+)$ & $\mathrm{c}+\mathrm{t+}$ & & & As \\
\hline & & & $13+\times 2$ & FvifS-m & $85-125$ & $7.5 Y R 4.6$ (10YR5i8) & 24 & 3 ve AB-P & + & $(+)$ & + & + & & & As \\
\hline & & & $2 \mathrm{Bg}$ & $\mathrm{F}(\mathrm{mSS})-\mathrm{m}$ & 125.150 & 10YR5:8 & 18 & $2 e s B$ & +4 & + & $(+)$ & + & & + & $\mathrm{Ai}$ \\
\hline & & & 2Btg & $\mathrm{m} / \mathrm{SF}-\mathrm{m}$ & $150-180$ & IOYR $5: 8$ & 6 & $2 \mathrm{cSB}$ & + & $(+)$ & $\Leftrightarrow$ & $m+$ & & + & A s dipping NW \\
\hline & & & $2 \mathrm{BtgCC}$ & $\mathrm{SF}-\mathrm{m}$ & $180-2044$ & $10 Y R 56$ & 12 & $3 \mathrm{~m} \mathrm{SB}$ & ++ & $+\pi$ & $(+)$ & & & + & $C_{5}$ \\
\hline & & & $3 \mathrm{BCg}$ & meSA & $204-230$ & 10YR5:6 & 24 & $3 \mathrm{mSB}$ & +.. & + & - & & & + & As \\
\hline & & & $3 \mathrm{Cg}$ & $\mathrm{mSA}$ & $230-250$ & 10YR 56 & 24 & $3 \mathrm{~m} \mathrm{SB}$ & +- & + & - & & & & Gs \\
\hline & & & $3 \mathrm{CH} 2$ & $\operatorname{meSA}$ & $250-320$ & $10 \mathrm{YR} 5 \mathrm{~s}$ & 24 & $3 \mathrm{~m} \mathrm{SB}$ & +++ & +++ & $(+)$ & & & & Gs \\
\hline & & & $3 \mathrm{Cg} 3$ & $\mathrm{mfS}$ & $320-370$ & 10YR5:8 & 24 & $3 \mathrm{mAB}$ & $++4+$ & & $(+)$ & & & & As \\
\hline & & & $3 \mathrm{Cg} 4$ & $m e S-t$ & $370-420$ & 10YR5:8 & 24 & $3 \mathrm{mAB}$ & +1+m+ & + & $(+)$ & & & & As \\
\hline & & & $3 \mathrm{Cg} 5$ & $\mathrm{mS} / \mathrm{A}$ & $420-450$ & $10 Y R 5: 8$ & 24 & $3 \mathrm{mAB}$ & +++4 & + & $(+)$ & & & & As \\
\hline & & & $3 \mathrm{C}$ & $\mathrm{mes}$ & $450-550-$ & loYR5:8 & 24 & & ++- & + & $(+i$ & & & & nd \\
\hline \multirow[t]{12}{*}{ SC4 } & $\overline{\mathrm{ABF}}$ & 79 & $\mathrm{Bgt}$ & $\mathrm{AF}(\mathrm{mfS})-\mathrm{m}$ & $0-70$ & $7.5 Y$ Y 4.4(10YR5.4) & 16 & $2 \mathrm{mAB}-\mathrm{P}$ & + & + & $(+)$ & +4 & & & $\mathrm{CS}_{\mathrm{s}}$ \\
\hline & & & Bget & $\mathrm{FA}(\mathrm{mfS})-\mathrm{m}$ & $70-100$ & $7.5 Y R 4.4(2.5 Y 61)$ & 16 & $2 \mathrm{rAB}$ & + & + & $(+)$ & & & & Gs \\
\hline & & & Begt & $\mathrm{AF}(\mathrm{mrS})-\mathrm{m}$ & $100-115$ & $7.5 \times R 4.4(2.5 Y 6.1)$ & 16 & $2 \mathrm{fAB}$ & ++ & $+1+1+\mathbf{n}$ & + & & & & Gis \\
\hline & & & Begt2 & $\mathrm{AF}(\mathrm{mfS})-\mathrm{m}$ & $115-120$ & $7.5 \times R 44(2.5 \times 61)$ & 16 & $2 \mathrm{fAB}$ & ++ & $++1++n$ & + & & & + & $\mathrm{Ai}$ \\
\hline & & & $2 \mathrm{Btg}$ & $\mathrm{FA} \cdot \mathrm{AF}-\mathrm{m}$ & $120-145$ & $7.5 \mathrm{YR} 4.4(2.5 \mathrm{Y} 61)$ & 16 & $2 \mathrm{mc} \mathrm{AB}$ & ++ & & +4 & & & + & Cs \\
\hline & & & $2 \mathrm{Bgt}$ & $\operatorname{mcF}(15)-m$ & $145-200$ & $10 Y R 44$ & 12 & $2 \mathrm{fAB}$ & & + & ++ & & & & Gis \\
\hline & & & $2 \mathrm{Bgt} 2$ & $\mathrm{FA}(\mathrm{S})-\mathrm{m}$ & $200-240$ & 10YR4:4 & 12 & $2 \mathrm{fAB}$ & + & + & + & & & & As \\
\hline & & & 3Btcg & $\mathrm{A}(\mathrm{F})-\mathrm{m}$ & $240-300$ & 7.5 YR5 8 (10YR7/1) & 24 & $2 \mathrm{mAB}$ & ++4 & $+1+$ & $+11+$ & + & & & Gs \\
\hline & & & $3 \mathrm{Btg} 2$ & $\mathrm{FA}-\mathrm{m}$ & $300-335$ & $7.5 Y R 56$ & 24 & $1 \mathrm{fAB}$ & ++ & $+1++$ & ++ & + & & & $\mathrm{Cs}$ \\
\hline & & & 4Beg & SAF & $335-420$ & $10 Y R+4$ & 12 & $3 \mathrm{cAB}$ & & + & & + & + & & $\mathrm{Cs}_{5}$ \\
\hline & & & $4 \mathrm{Bg}$ & FS & $420-440$ & 10YR44 & 12 & . & - & + & & + & & & $\mathrm{C}_{5}$ \\
\hline & & & $4 \mathrm{BCg}$ & $m S(A)$ & $440-550-$ & $10 Y R 44$ & 12 & . & . & + & . & + & + & & nd \\
\hline \multirow[t]{13}{*}{ CAS } & $\begin{array}{ll}\mathbf{A} 03 \\
\end{array}$ & 68 & Apl & $F+F$ & $0-20$ & & & $1 \mathrm{fG}$ & $=$ & - & $=$ & & & - & As \\
\hline & & & Ap 2 & $\mathrm{FS}-\mathrm{m}$ & $20-33$ & $2.5 \times 5.6$ & 6 & $3 \mathrm{mG}$ & - & & & & & . & $A w$ \\
\hline & & & $\mathrm{CB}$ & FS-m & $33-45$ & $2.5 \times 5.6$ & 6 & $3 \mathrm{mAB}$ & & $(+)$ & - & & & - & As \\
\hline & & & $2 \mathrm{Btg}$ & $\mathrm{FS}-\mathrm{m}$ & 45.90 & $2.5 Y 6.4(10 Y R 6.8)$ & 4 & $3 \mathrm{~m} \mathrm{AB}$ & ++ & +++ & + & & & & Gs \\
\hline & & & 2Bxg & $F-m$ & $90-147$ & $2.5 \mathrm{Y8} / 3(10 \mathrm{YR} 7 / 8)$ & 3 & $3 \mathrm{c} \mathrm{AB}-\mathrm{P}$ & +++ & $++n$ & & & & . & $\mathrm{Ai}$ \\
\hline & & & $2 \mathrm{Cgk}$ & AF & $147-150$ & $2.5 \times 7 / 3$ & 3 & & & $+1+n$ & $(+)$ & & & & \\
\hline & & & 3Btg & $\mathrm{ms}$ & $150-242$ & 10YR5: (10YR\& 2 ) & 24 & & + & $+1+n$ & + & & +H+ & & Gs \\
\hline & & & $3 \mathrm{Cl}$ & Fvis-m & $242-247$ & $2.5 \times 7 / 4$ & 4 & . & & & . & & & & Gs \\
\hline & & & $3 \mathrm{C} 2$ & $\mathrm{f}-\mathrm{es}$ & $247-289$ & 10YRS:8 & 24 & . & & +++ & . & & & & Gis \\
\hline & & & $3 \mathrm{C} 3$ & & $289-303$ & $10 \mathrm{YR} 46$ & 18 & & & & - & & & & Gs \\
\hline & & & $3 \mathrm{C} 4$ & $\operatorname{meS}(\mathrm{F})$ & $303-379$ & 10YR5.6 (10YR6:2) & 18 & $2 \mathrm{mG}$ & +H & + & & & & & Gs \\
\hline & & & $4 \mathrm{BCg}$ & $\mathrm{cmS}$ & $379-459$ & 10YR5:8 & 24 & $3 \mathrm{eP}$ & & +++ & $(+)$ & $\mathrm{f}++++$ & & - & $A w$ \\
\hline & & & $4 C^{\circ}$ & $\mathrm{cms}-1$ & 459.569 & 10YR 44 & 12 & - & & & - & & & . & nd \\
\hline
\end{tabular}

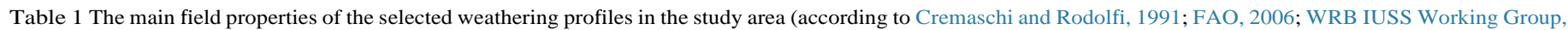

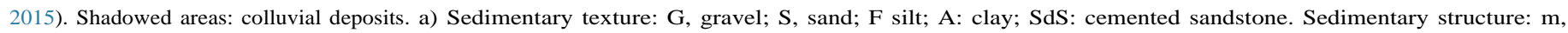

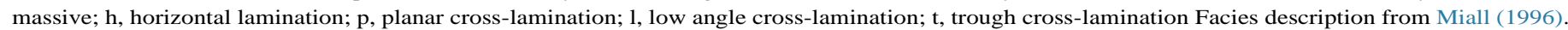

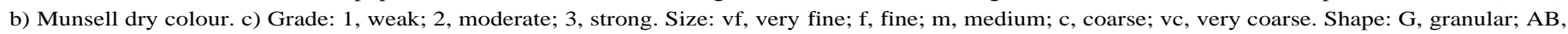

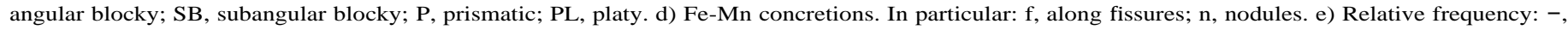

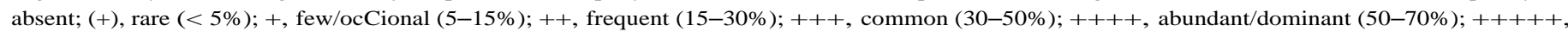

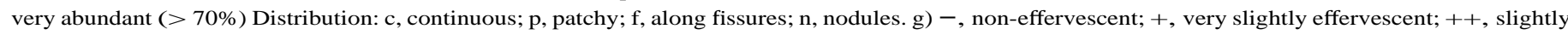

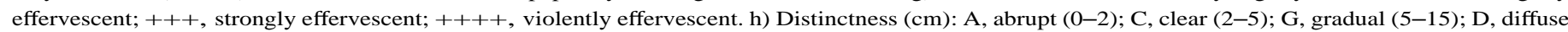
(> 15). Topography: s, smooth; w, wavy; i, irregular (FAO, 2006); nd, not detected.

\subsubsection{Soils in SC3, the northernmost fault block}

Profile A53 belongs to the INS terrace on the northern slope of the San Colombano hill (Figs. 1B, 3), within the intermediate fault-block corresponding to morphological sector SC3. As the fault blocks adjacent to SC3 represent the downthrown hangingwall, this INS terrace is relatively uplifted above the correlative ones in the adjacent SC4 and PML sectors. From the top, profile A53 shows 1,25 m of L2 loess (Fig. 4) and a colluvial package above $S_{1-1}$ and the INS alluvial sands below. It involves a very strongly acid soil (Table 2, Fig. 3B) developed from L2 down to the underlying colluvial and alluvial deposits. Massive silty sands and yellowish-brown colours prevail in the uppermost $85 \mathrm{~cm}$ (L2; Fig. 6A); grain-size increases downwards (Fig. 4) and colours turn into reddish brown (Table 1; Fig. 3B), typical of hydromorphic conditions. Micromorphological analyses reveal that the uppermost horizons contain very rare cc, few rounded, orange illuvial papules and common evidences of bioturbation (passage pedofeatures; Stoops et al., 2010). Two generations of illuvial pedofeatures have been observed in horizons Bw, Btx and Btx2 (Fig. 6C). The first, rarely assimilated into the groundmass, is made of impure, laminated brown-orange clays with high birefringence; it is superposed by compound layers of dusty-tolimpid microlaminated coatings, in contact with voids. Coatings are thicker in Btx, where incipient slickensides define a striate microstructure. 
Between the base of $\mathrm{L} 2_{2}$ and $\mathrm{S}_{1-1}$, a moderate effervescence and an increasing soil structure (Table 1) have been registered, together with a downward decrease of both redness index and AIR (Table 2; Fig. 3B). The horizon 2Bg, characterized by a bimodal grain-size distribution (Fig. 4), contains very few illuvial coatings, which show comparable features of the cc of the overlying horizons. Within $2 \mathrm{Btg}$ and $2 \mathrm{Btgc}$, frequent anorthic nodules, red papules and fragments of juxtaposed cc (Fig. 6D), reworked soil fragments (i.e. pedorelicts sensu Brewer, 1964) of strongly weathered material, often oriented along NW-dipping laminae, are present. The $\mathrm{cm}$-sized sub-rounded soil fragments strongly contrast (finer textures, thicker relic cc and prevailing orange colours) with the greyish, sandy groundmass of these horizons. Concerning the pedorelicts, the degree of weathering increases from $2 \mathrm{Bg}$ towards $2 \mathrm{Btgc}$ horizons. The present-day voids within the horizon $2 \mathrm{Btg}$, are not coated; by contrast, in situ pedofeatures occur in the horizon $2 \mathrm{Btgc}$, and consist in juxtaposed, thick orange microlaminated cc overlying compound layers of laminated orange, dusty clays and granular infillings (Fig. 6E).

Below the surface $S_{1-1}$, medium- to coarse-grained sands compose a sequence of BC to C horizons (Fig. 3; Table 1), that are marked by frequent gley features (Fig. 6B). Sand petrography records abundant sedimentary and effusive volcanic lithics as common for INS sediments. Thick, orange microlaminated cc coat the main channels; depletion pedofeatures postdate all the previous ones (Fig. $6 \mathrm{~F}$ ).

\section{Interpretation}

The described soil does not show evidence of complex polygenesis. The presence of only fresh coatings in contact with voids suggests that the pedogenesis occurred under a period of generally stable interglacial conditions, whose contrasting seasonality has been registered in the juxtaposed textures of cc. The soil developed from the top of L2, which represents the morphological surface of stabilization corresponding to the present-day topography. An older phase of dusty clay translocation was probably observed below $\mathrm{S}_{1-1}$, where coarse infillings mark the end of stabilization and pedogenesis and the beginning of a climate cooling, consistent with the subsequent L2 loess deposition. Grain-size distribution confirms that poorly weathered loess deposits are present on top and followed the deposition of the alluvial INS. Moreover, the abrupt change in clay content and A.I.R., the redder colours and the occurrence of relic key-features sensu Mroczek (2013), contributed to interpret the material interposed between INS and L2, i.e. just above surface $S_{1-1}$, as a colluvium. It contains several relicts of well-developed and hydromorphic paleosols, but not comparable to the degree of pedogenesis of the profile A53; this evidence, together with the inverse paleo-pedological sequence marked by an upward-decrease of degree of weathering of the pedorelicts, suggests that an abrupt event of paleosol mobilization and redeposition took place before the loess aggradation.

\begin{tabular}{|c|c|c|c|c|c|c|c|c|c|c|c|c|c|}
\hline \multirow{2}{*}{ 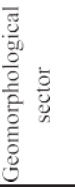 } & \multirow[b]{2}{*}{$\frac{2}{\frac{D}{2}}$} & \multirow[b]{2}{*}{ 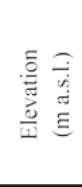 } & \multirow[b]{2}{*}{ Horizon } & \multirow[b]{2}{*}{ Depth $(\mathrm{cm})$} & \multicolumn{3}{|c|}{ Particle size distribution ( $\%)$} & \multirow[b]{2}{*}{$\mathrm{pH}\left(\mathrm{H}_{2} \mathrm{O}\right)$} & \multirow[b]{2}{*}{$\begin{array}{l}\text { Organic } \\
\text { matter }\end{array}$} & \multicolumn{3}{|c|}{ Iron forms $\left(\mathrm{g} \mathrm{kg}^{-1}\right)$} & \multirow[b]{2}{*}{ AIR } \\
\hline & & & & & $\begin{array}{c}\text { Sand } \\
63 \mu \mathrm{m}-2 \mathrm{~mm}\end{array}$ & $\begin{array}{c}\text { Silt } \\
2-63 \mu \mathrm{m}\end{array}$ & $\begin{array}{l}\text { Clay } \\
<2 \mu \mathrm{m}\end{array}$ & & & $\mathrm{Fe}_{\mathrm{p}}$ & $\mathrm{Fe}_{\mathrm{d}}$ & $\mathrm{Fe}_{\mathrm{o}}$ & \\
\hline \multirow[t]{4}{*}{$\mathrm{SC} 1$} & \multirow[t]{4}{*}{$\overline{\mathrm{A} 1}$} & \multirow[t]{4}{*}{140} & \multirow{4}{*}{$\begin{array}{l}\mathrm{Btx} \\
2 \mathrm{Bck} \\
2 \mathrm{Btgc} \\
2 \mathrm{CB}\end{array}$} & $60-110$ & 5 & 76 & 19 & 6.6 & 1.8 & 1.1 & 21.7 & 2.6 & 0.12 \\
\hline & & & & $110-155$ & \multirow{3}{*}{$\begin{array}{l}5 \\
148\end{array}$} & \multirow{3}{*}{$\begin{array}{l}61 \\
63_{21}\end{array}$} & \multirow{2}{*}{$\begin{array}{l}34 \\
2 \xi_{1}\end{array}$} & \multirow{2}{*}{$\begin{array}{l}7.1 \\
6.9 .8\end{array}$} & \multirow{2}{*}{$\begin{array}{l}1.9 \\
10.5\end{array}$} & \multirow{2}{*}{$\begin{array}{l}3.8 \\
1,0.6\end{array}$} & \multirow{2}{*}{$\begin{array}{l}24.6 \\
2.36 .9\end{array}$} & \multirow{2}{*}{$\begin{array}{l}0.9 \\
6.9 \\
1.4\end{array}$} & \multirow{2}{*}{$\begin{array}{l}0.04 \\
>0.04\end{array}$} \\
\hline & & & & $\begin{array}{l}155-310 \\
310-490\end{array}$ & & & & & & & & & \\
\hline & & & & $490-680$ & & & 20 & 7.7 & 0.6 & 1.5 & 6.0 & 0.4 & 0.06 \\
\hline \multirow[t]{12}{*}{$\mathrm{SC} 2$} & \multirow[t]{12}{*}{ A44 } & \multirow[t]{12}{*}{115} & $\mathrm{Ap} / \mathrm{Ep}$ & $0-20$ & & & & 5.9 & 9.6 & 3.0 & 12.1 & 4.3 & 0.36 \\
\hline & & & Bw & $20-40$ & 6 & 75 & 19 & 6.4 & 2.0 & 1.6 & 11.7 & 2.5 & 0.21 \\
\hline & & & $\mathrm{Btx}$ & $40-70$ & 4 & 82 & 14 & 6.4 & 2.0 & 1.4 & 11.2 & 2.0 & 0.18 \\
\hline & & & $\mathrm{Bt}$ & $70-110$ & 7 & 76 & 17 & 6.4 & 1.2 & 1.5 & 10.4 & 1.4 & 0.13 \\
\hline & & & $2 \mathrm{Bt} 2$ & $110-140$ & 10 & 65 & 25 & 6.5 & 2.6 & 2.8 & 12.4 & 1.4 & 0.11 \\
\hline & & & $2 \mathrm{Btc}$ & $140-220$ & 19 & 42 & 39 & 6.2 & 0.9 & 4.3 & 15.7 & 0.9 & 0.06 \\
\hline & & & $3 \mathrm{Bt} 3$ & $220-240$ & 35 & 37 & 28 & 6.5 & 2.4 & 3.1 & 10.1 & 0.9 & 0.09 \\
\hline & & & $3 \mathrm{Btg}$ & $240-260$ & 44 & 37 & 19 & 6.9 & 0.5 & 2.1 & 7.7 & 0.6 & 0.08 \\
\hline & & & $\mathrm{Bw}$ & $0-110$ & 28 & 50.5 & 21.5 & 7.0 & 2.3 & - & - & - & - \\
\hline & & & $\mathrm{Bt}$ & $110-130$ & 71.5 & 19 & 9.5 & 7.2 & 1.2 & - & - & - & - \\
\hline & & & Bt2 & $130-160$ & 76.5 & 18.5 & 5 & 7.2 & 1.3 & - & - & - & - \\
\hline & & & $\mathrm{BC}$ & $160-180$ & 85 & 13.5 & 1.5 & 7.2 & 0.1 & - & - & - & - \\
\hline \multirow[t]{9}{*}{$\mathrm{SC} 3$} & \multirow[t]{9}{*}{ A53 } & 85 & $\mathrm{~A} 1$ & $3-13$ & 9 & 77 & 14 & 4.2 & 23.8 & 2.7 & 6.5 & 3.3 & 0.51 \\
\hline & & & $\mathrm{A} 2$ & $13-40$ & 11 & 74 & 15 & 4.9 & 7.6 & 2.6 & 6.5 & 2.7 & 0.42 \\
\hline & & & $\mathrm{Bw}$ & $40-68$ & 7 & 75 & 18 & 4.4 & 7.0 & 3.2 & 7.1 & 3.0 & 0.43 \\
\hline & & & Btx & $68-85$ & 6 & 75 & 19 & 4.5 & 5.3 & 4.1 & 12.1 & 4.2 & 0.35 \\
\hline & & & $\mathrm{Btx} 2$ & $85-125$ & 7 & 69 & 24 & 4.9 & 4.0 & 5.1 & 8.1 & 6.3 & 0.78 \\
\hline & & & $2 \mathrm{Bg}$ & $125-150$ & 11.5 & 68.5 & 20 & 5.7 & 2.7 & 3.7 & 10.4 & 4.4 & 0.43 \\
\hline & & & 2Btg & $150-180$ & 27.5 & 51 & 21.5 & 4.8 & 10.3 & 3.4 & 12.9 & 2.5 & 0.20 \\
\hline & & & $2 \mathrm{Btgc}$ & $180-204$ & 36 & 31.5 & 32.5 & 5.5 & 1.7 & 3.1 & 9.5 & 1.3 & 0.14 \\
\hline & & & $3 \mathrm{BCg}$ & $204-230$ & 45.5 & 23 & 31.5 & 5.2 & 2.6 & 4.5 & 11.2 & 1.1 & 0.09 \\
\hline $\mathrm{SC} 4$ & $\mathrm{ABF}$ & 79 & $\begin{array}{l}\mathrm{Bgt} \\
2 \mathrm{Btg} \\
2 \mathrm{Bgt} 2\end{array}$ & $0-70$ & 4 & 72 & 24 & & & - & - & - & - \\
\hline
\end{tabular}

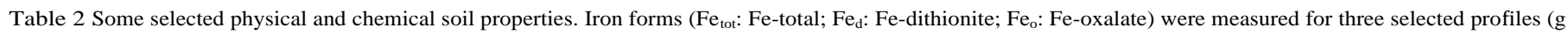

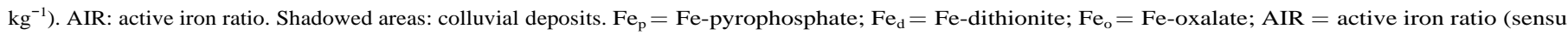
Cremaschi and Rodolfi, 1991). 

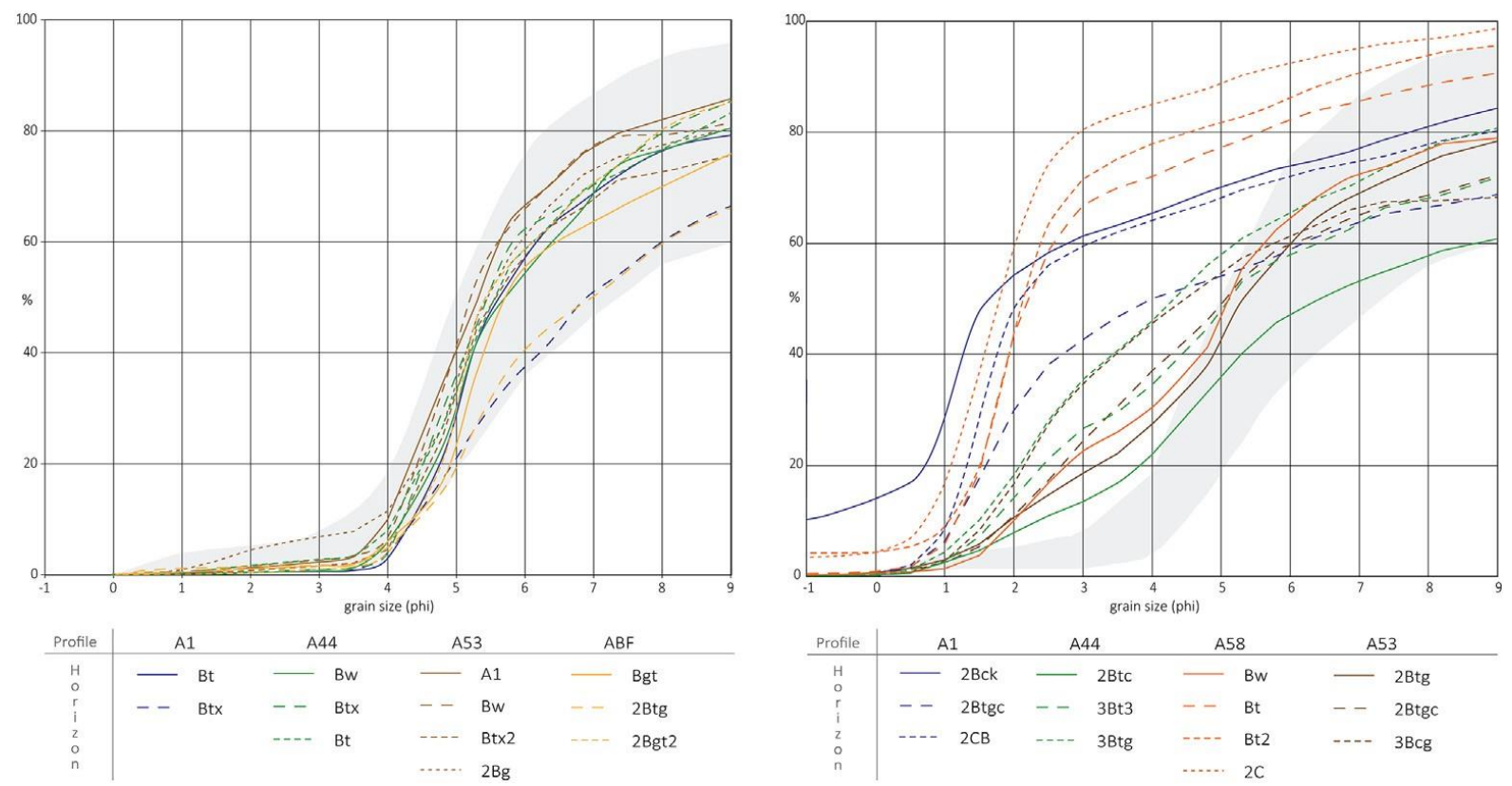

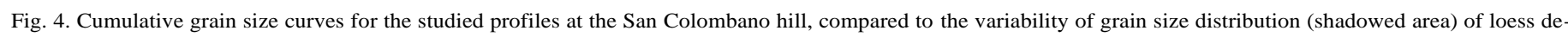

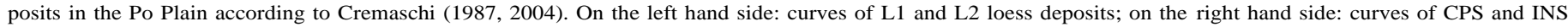
deposits.

\subsubsection{Soils in SC2, the intermediate fault block}

Profile A44 characterizes the geomorphological sector corresponding to the fault-block adjacent to and lowered by about $15-20 \mathrm{~m}$ compared to SC1. From top to bottom, profile A44 involves silty loess (L2; Fig. 4) which stands at the top of a reworked, colluvial deposit, the latter covering the CPS alluvial sands through $\mathrm{S}_{1-1}$ (Figs. 3, 6G). Profile A44 comprises two soils with a general slightly acid pH, neutral towards the bottom (Fig. 3B; Table 2). The shallower soil was observed within L2 and shows three generations of illuvial coatings. The older ones, as thin coatings of dusty brown laminated clay are covered by thicker, orange cc with high birefringence. These are both degenerated due to the intense bioturbation, which increases downward, often isolating illuvial papules; the youngest generation of orange, non-laminated and limpid cc superimposed on the older ones, is characterized by more unbroken surfaces. Clay coatings generally form compound layers with Fe-Mn hypocoatings (Fig. 6H).

The reworked, NW-dipping stratified silts to coarse-sized sands (bimodal grain-size distribution; Fig. 4) occur between the bottom of L2 and $\mathrm{S}_{1-1}$ surface; these deposits are characterized by reddish colours, more resistant structures, diffuse calcium carbonate (weak effervescence; Table 1) and rounded, mm-sized Fe-Mn nodules (2Bt2 and 2Btc horizons, Fig. 3). In thin section, they show frequent pedorelicts of finer and more illuviated material than the groundmass (Fig. 6I), weathered sand clasts, deformed papules and common, rounded and degraded Fe-Mn nodules, more abundant in the horizon 2Btc. Cc are rare within the recent voids and are similar to the generations of cc described in the overlying horizons; relicts of thick, compound layers of impure-to-silty coatings and limpid, laminated orange cc are present in the horizon 2Btc and weakly oriented in a striated b-fabric. Mineral assemblage is typical of a subarkose with common sedimentary rock fragments; anyway, the petrographic composition shows an increase in sedimentary lithics compared to the underlying sediments (CPS). A.I.R. is lower in this unit than in the overlying horizons (Table 2; Fig. 3B). The lowermost values of A.I.R. and $\mathrm{pH}$ were registered in correspondence to the horizon $2 \mathrm{Btc}$.

An abrupt change in sand petrography and soil features occurs across $S_{1-1}$ : metamorphiclastic litharenites become dominant and different pedogenic features have been observed in correspondence of the horizons 3Bt3, 3Btg, 3BC. Two generations of illuvial coatings have been detected: the older crescent laminated coating of brown clay (Fig. $6 \mathrm{~J}$ ) are overlain by thicker, compound layers of limpid to dusty orange cc, very rarely connected to voids. Redoximorphic features as Fe-Mn nodules and groundmass impregnations are intensively degraded (3Btg horizon, Fig. 6K). Rare intergranular, dusty brown illuviation in a pellicular microstructure is present towards the bottom of the profile (3BC horizon; Table 3 ). A late phase of depletion, evidenced by the pale colour of the groundmass surrounding the main voids, characterizes the CPS sands.

\section{Interpretation}

The absence of topsoil horizons and the presence of several B horizons, indicate that a partial truncation of the surface of stabilization on top of CPS occurred before the deposition of L2. The degree of fragmentation, the abundance and thickness of the cc and the degradation of the Fe-Mn impregnations of the horizons below $\mathrm{S}_{1-1}$, suggest moister and more oxidizing conditions than the present-day climate, attributable to a Quaternary interglacial. The detection of several reworked relic pedofeatures, corroborated by sedimentary evidences and A.I.R. measurements, indicate that paleosol redeposition took place originating the colluvium above $S_{1-1}$. Colluviation processes may explain the slight truncation of the topsoil of CPS. Moreover, the change in petrography suggests that different sediments (with a petrographic finger-print comparable to the compositional features of INS) were available in the source-area. Since the colluviated horizons (i.e. 2Bt2 and 2Btc) do not show significant in situ illuvial pedofeatures, the registered clay enrichment is arguably interpreted as the result of paleosol reworking; the only exception is the dusty orange coatings, followed by the thin, undegenerated cc. These ones, also common to the L2 loess cover, constitute the latest phase of clay illuviation, formed under wet conditions, and subsequent to the deposition of the L2 loess on top of the profile. 


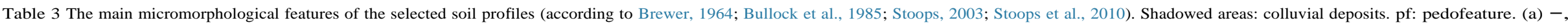

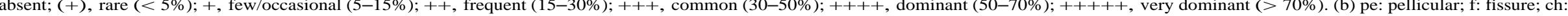

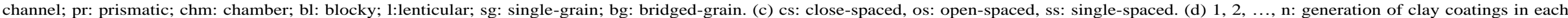
sample. (e) c: cryogenic, p: passage, sl: slickenside.

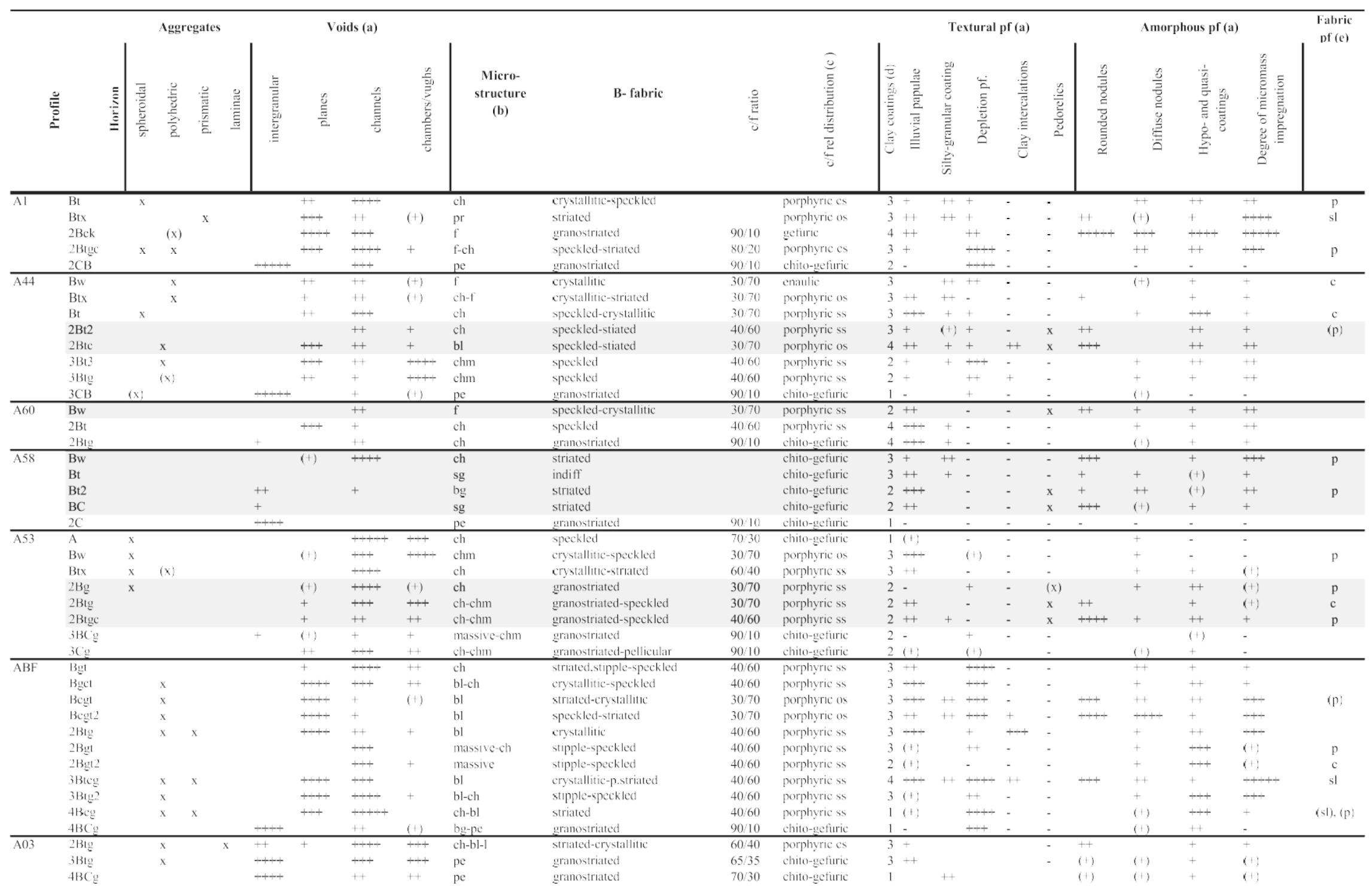



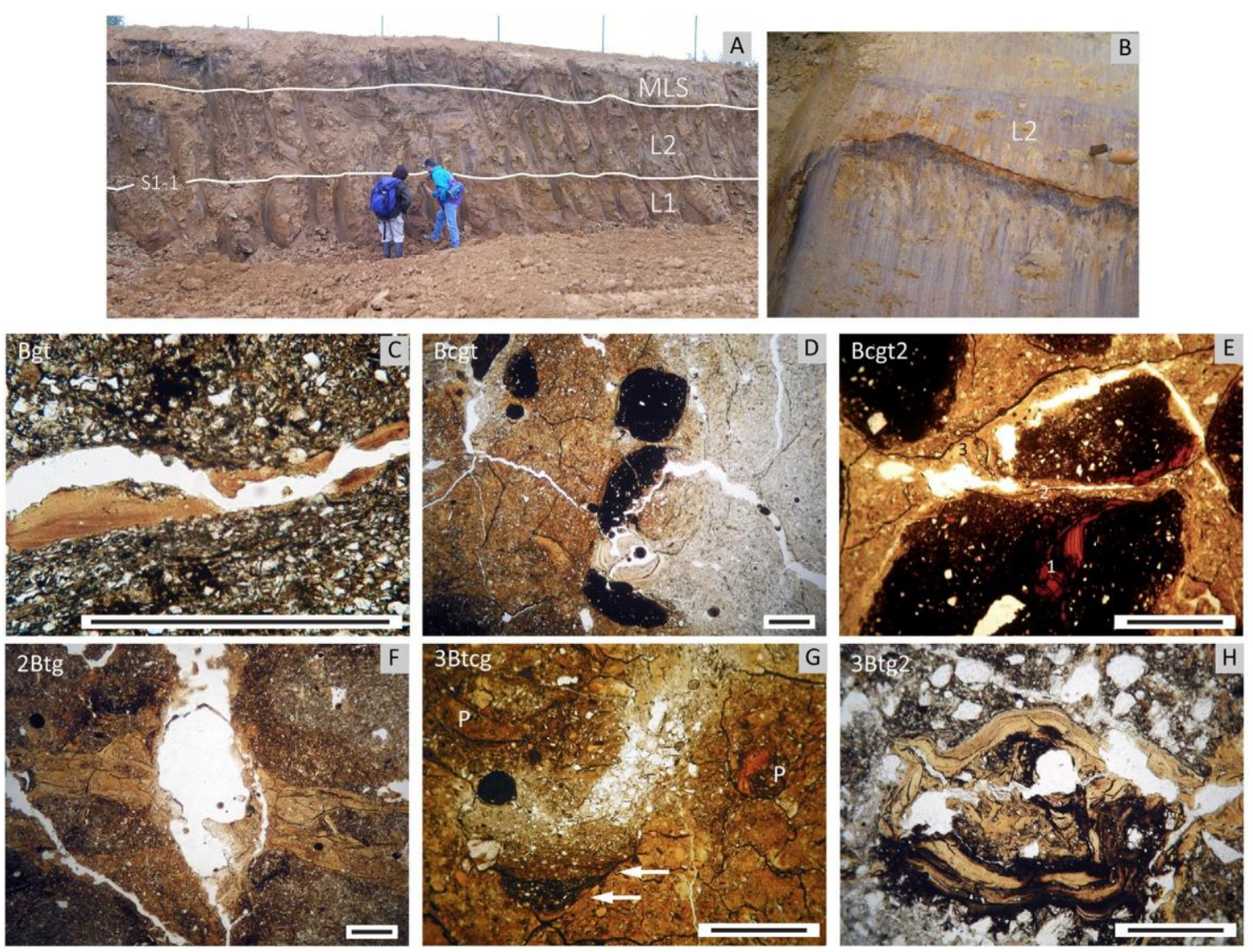

Fig. 5. Soil profile ABF, geomorphological sector SC4 (San Colombano hill). A) Two blankets of loess crop out at the top of the cross-section (L1 and L2). B) Detail of the Fe-Mn crust developed in correspondence to the horizon Bcgt horizon. C-H) Micromorphological features of ABF; PPL: plane polarized light; XPL: crossed polarized light. C) Compound pedofeature of laminated coatings of dusty clays with traction structures, and limpid nonlaminated, orange clay coatings in a sub-horizontal channel; PPL. D) The first generation of illuvial coatings is strongly fragmented and dispersed in the groundmass. Subrounded, typic dense Fe-Mn nodules are fragmented and coated by a second generation of laminated coatings of dusty brownishorange clays. The largest channels are coated by thicker and more limpid, laminated clays. The strong contrast between the two sides of the picture results from a last phase of depletion along the most conductive voids; PPL. E) Orthic typic Fe-Mn nodule grew up on a limpid, laminated clay coating (1). Feimpregnation has been followed by renewed pedoturbation and coating by two juxtaposed generations of orange silt and clay (2,3). F) Silty micromass impregnated by Fe-Mn quasicoatings is crossed by thick, sub-horizontal clay intercalations (sensu Fedoroff and Courty, 2012); PPL. G) A stratified silty infilling (arrows) cross-cuts thick, orange clay intercalations (sensu Fedoroff and Courty, 2012). Rounded fragments of older, reddish, compound illuvial pedofeatures (P) are dispersed in the groundmass; PPL. H) Compound pedofeature of the youngest generation of limpid orange clay coating and Fe-Mn hypocoatings; PPL. Scale bars: $1 \mathrm{~mm}$.

Profile A60 (Fig. 7A) has been described from the sub-planar top of sector SC2 and involves, from the top, the colluviated sandy silt of L2 loess and the alluvial sands to clayey sands belonging to CPS, bounded by surface $S_{1-1}$ (Fig. 3). This surface gently dips NW and separates different sets of pedofeatures. Above $S_{1-1}$, the Bw silty horizon contains rare and thin cc within the present-day voids; conversely, orange to red laminated papules, rounded Fe-Mn nodules coating thick cc (Fig. 7B) and subangular relicts of weathered sediment are common. The presence of carbonates in $\mathrm{Bw}$ is deduced from a moderate effervescence of sediments (Table 1). Differently, below $\mathrm{S}_{1-1}$, we distinguished 2Bt, $2 \mathrm{Btg}$ and $2 \mathrm{BC}$ horizons; speckled b-fabrics characterize horizons $2 \mathrm{Bt}$ and $2 \mathrm{Btg}$, while a granostriated b-fabric has been described in $2 \mathrm{BC}$ horizon. At least two distinct generations of cc occur: the oldest consists of laminated coatings of brown, impure clay; they frequently form compound pedofeatures with silt coatings, showing traction structures (Fig. 7C); the youngest generation is made of more limpid-orange, non-laminated cc. Fe-Mn hypocoatings and rare, diffuse nodules are common. Illuvial red clayey papules and fragments of dusty impure coatings are common and strongly assimilated into the soil matrix, so their relative chronology with the other pedofeatures is hardly recognizable.

\section{Interpretation}

The high abundance of papules, rounded nodules and pedorelicts above $S_{1-1}$ is an evident indication of paleosol reworking. Below $S_{1-}$ ${ }_{1}$, the degree and type of coatings degeneration suggest that clay coatings are relict features related to interglacial/interstadial stage and fragmented by bioturbation processes, as potentially deducible from the pervasive channel microstructure. Superposed silty coatings suggest that later periglacial conditions took place. The most recent phase of clay translocation crosses $S_{1-1}$ and registers a latest period of stable pedogenesis under interglacial conditions. The presence of an older pedogenetic phase, whose relicts of illuviation are preserved as papules and which was totally superposed by the described pedogenetic cycle, has not to be excluded. 

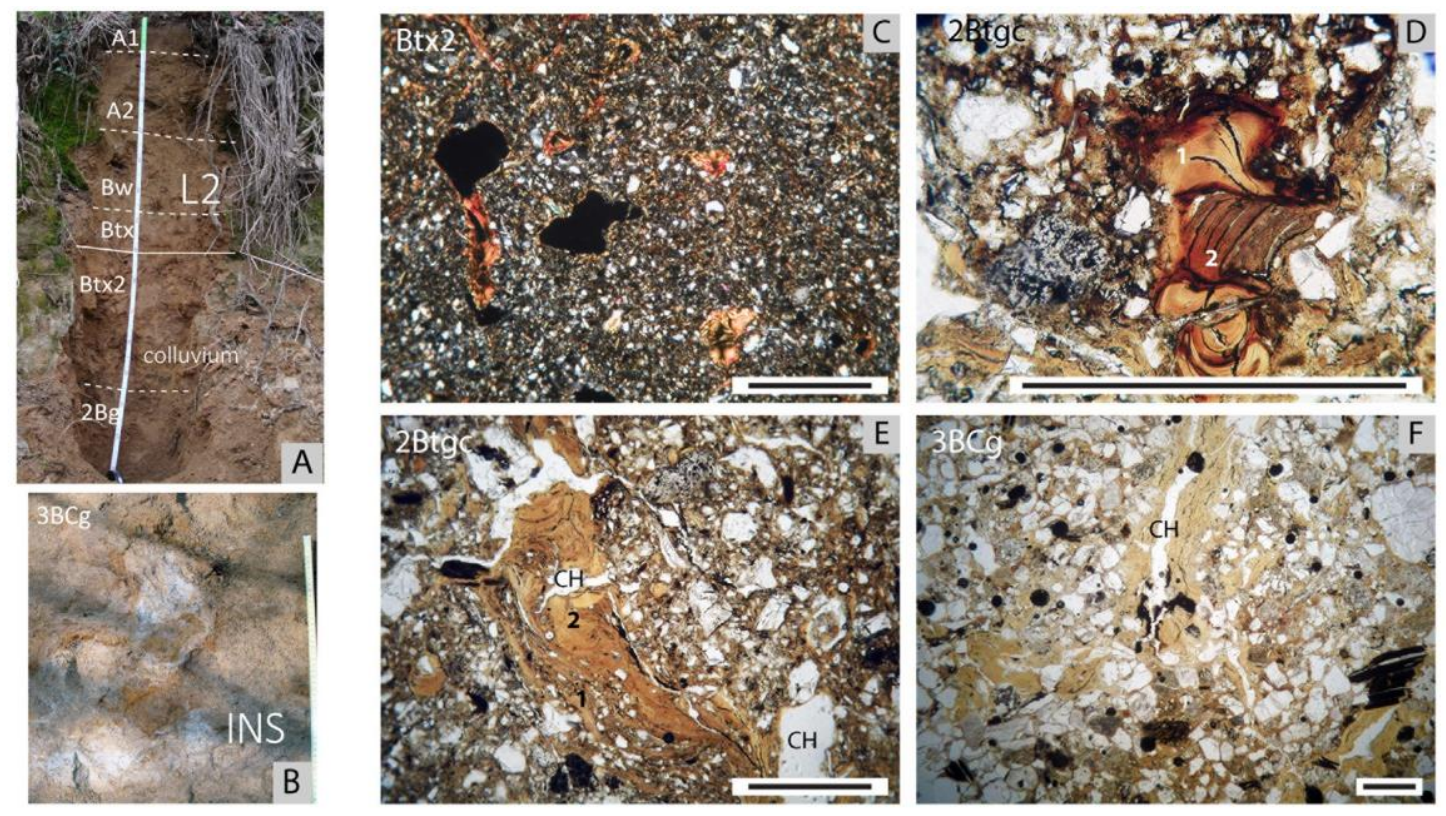

.
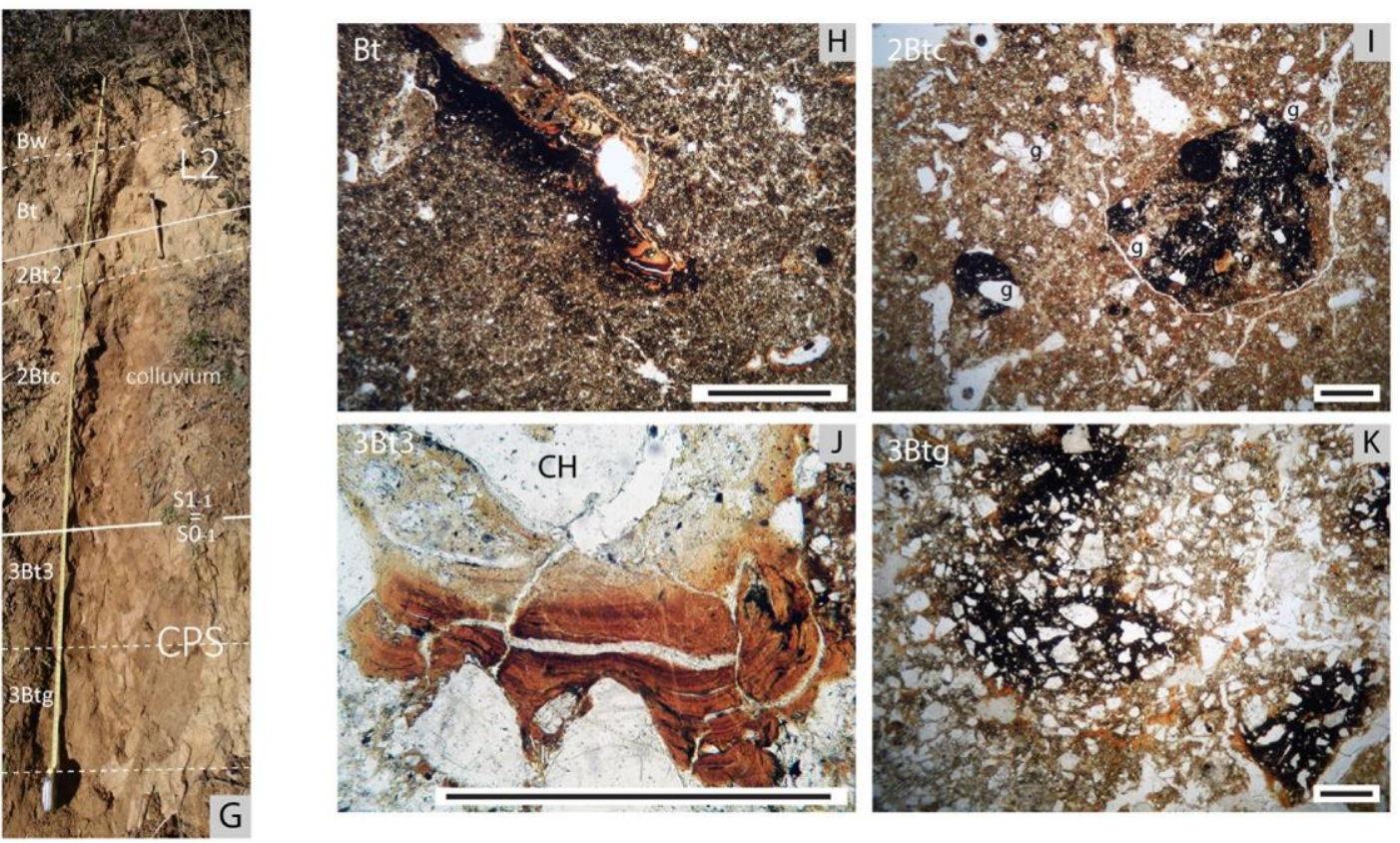

Fig. 6. A-F) Soil profile A53, sector SC3 (San Colombano hill); A) Soils horizons at the top of the cross-section (L2 loess); dashed line: gradual boundary; soild line: abrupt boundary. B) Detail of the gley features observed in the basal horizons of the profile (alluvial INS). Light grey irregular tongues are bordered by Fe-oxides. C-F) Micromorphological features of A53. C) Thin birefingent clay coatings and infillings in contact with voids; XPL. D) Reworked fragment of two juxtaposed generations of illuvial pedofeatures: 1) compound pedofeature of pure clay coatings with convolute laminas and Fe-hypocoatings; 2) crescent laminated coating of brown dusty clay. On the left hand side: strongly weathered fragment of volcanic rock; PPL. E) Compound pedofeature of coarse coatings (1) overlapped by a thick, orange-brown, poorly laminated clay coating (2) in contact with the channel (CH); PPL. F) Granostriated/pellicular microstructure. The first generation of coatings of dusty clays is overlaid by a typic yellowish-orange, limpid and poorly laminated clay coating in continuity with channels $(\mathrm{CH})$. Pale colours result from a later phase of depletion; PPL. G-K) Soil profile A44, sector SC2 (San Colombano hill): G) uppermost profile within L2 loess, buried colluvial deposits and alluvial CPS. $\mathrm{H}-\mathrm{K})$ Micromorphological features of A44: H) thin illuvial coatings in the L2 loess, associated with Fe-Mn hypocoatings; PPL. I) Pedorelict showing impregnative redox pedofeatures and clay illuviation, more pronounced than the $2 \mathrm{Btc}$ groundmass. Voids lack coating; $\mathrm{g}=$ sand-sized grain. J) Granular infilling ( $\mathrm{CH}=$ channel) above alternating crescent coating of dusty and limpid laminated clay; PPL. K) dark Fe-Mn oxides, at present degraded, impregnate two generations of laminated coatings (dusty brown and dusty/limpid orange clays); PPL. Scale bars: 1 mm.

Profile A58 locates in a narrow, $20 \mathrm{~m}$ deep valley in the central sector of the fault block SC2 (Figs. 1B, 3). At this site, a SE-dipping, concave-upward surface $\left(\mathrm{S}_{0-1}\right)$ is gullied into the truncated CPS and the gully is filled by reworked colluvial-alluvial sediments. Aggregate beds of yellowish, massive silt have been observed at the ground surface and on the valley slopes between 115 and $120 \mathrm{~m}$, and laterally correlated some metres above the sampled profile. These field evidences ascribed them to the loess L2. A58 profile was described from $105 \mathrm{~m}$ a.s.1. downwards and involves alluvial CPS and colluvial deposits; sediments are (clayey-) silty sand in texture above the surface $\mathrm{S}_{0-1}$, and sandy to gravelly-sand below it (Fig. 4). The upper profile consists of three B-horizons marked by brown-reddish matrix colours (Table 1; Fig. 3B) down to $S_{0-1}$ (Fig. 7D). A $20 \mathrm{~cm}$ thick, fine- to medium-sized gravel lag and recurrent, dm-sized mud clasts mark $\mathrm{S}_{0-1}$; 
gravels mostly consist of weathered clasts of metamorphic and volcanic rocks. Trough-cross laminations are clearly visible within the (gravelly) silty sands of BC horizon and paleocurrent measurement suggest SE-wards directed transport. Traction structures progressively disappear towards the horizon $\mathrm{Bw}$, while cc between peds increase along the same direction. A comparable increase in the clay fraction has been obtained from laboratory analyses (Table 2; Fig. 4). Angular blocky structure is common for B horizons and pH is neutral. At least three generations of illuvial coatings are present in thin section. The oldest one, orange micro-laminated, is frequently fragmented in the groundmass of the horizons $\mathrm{BW}$ and $\mathrm{Bt}$; comparable cc determine the bridged-grain to pellicular grain microstructure of horizon BC. The second generation consists of a compound pedofeature of dusty brown cc and silty coatings (Fig. 7E); it is common in the horizon $\mathrm{Bw}$, frequent in $\mathrm{Bt}$ and almost absent in $\mathrm{Bt} 2$ and BC. A third generation of orange, limpid cc follows. Subrounded to subangular, typic Fe-Mn nodules are frequent in horizon Bw; they display a sharp outline and a strong impregnation over sediments of finer texture than the surrounding groundmass, and are often degraded. Subrounded to subangular lithorelicts, and illuvial papules having comparable features of the first generation of cc, are common (Fig. 7F). 2C horizons developed on grey alluvial sands and gravelly sands below $\mathrm{S}_{0-1}$, showing weak subangular blocky structure in the reddish horizons, and no pedogenic structures in the grey sands; Fe-oxides precipitation occurred along the coarser-grained groups of laminae (Fig. $7 \mathrm{G}$ ). The frequent rock fragments are as weathered as above $\mathrm{S}_{0-1}$, but neither illuvial pedofeatures nor relic pedofeatures occur.

Interpretation

The abundance of relic pedofeatures (Fe-Mn nodules, highly illuviated pedorelicts) above the surface $\mathrm{S}_{0-1}$, the sedimentary traction structures described for horizons BC-Bt 2 and the measured paleocurrent orientations suggest that the surface $\mathrm{S}_{0-1}$ represents the bottom of a NW-SE-directed valley that incised the weathered CPS and truncated at least one well-expressed hydromorphic paleosol. The preserved sets of illuvial pedofeatures above $\mathrm{S}_{0-1}$ testify that the valley infilling subsequently stabilized and pedogenized. The illuvial silt on top of the profile suggests a change to pedogenesis typical of periglacial environments, that could be related to the phase of deposition of the massive L2 loess described on the adjacent slopes, or to a previous one, not preserved in this sector. Furthermore, the different orientation (NE-SW) and height of the present-day impluvium that cuts the described paleovalley, suggests that an abrupt diversion and a further deepening of the drainage pattern occurred after the extinction of the CPS paleovalley, presumably at the time of L2 loess deposition or later.
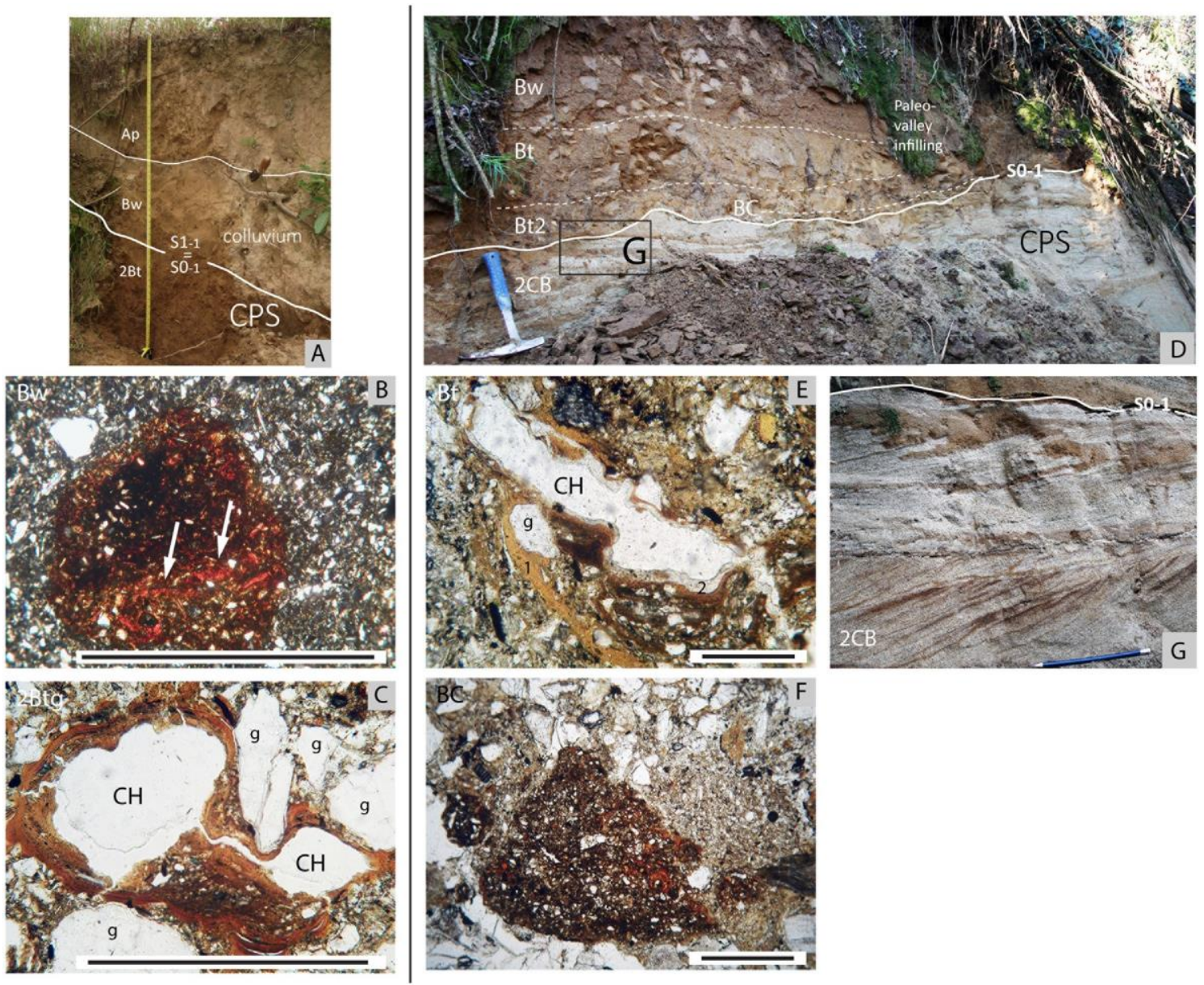

Fig. 7. A-C) Soil profile A60, sector SC2 (San Colombano hill). A) Abrupt boundary $\left(\mathrm{S}_{0-1}\right.$, here corresponding to $\mathrm{S}_{1-1}$ ) between the colluvium and the pedogenized CPS. B-C) Micromorphological features: B) Bw horizon. A typic Fe-Mn nodule impregnates an older generation of clay coatings (arrows) that is absent in the surrounding sediment; XPL. C) Cross-layered crescent infilling of silt and coarse clay $(\mathrm{CH}=\mathrm{channel})$ between two generations of laminated coatings of dusty and limpid clays. The youngest, limpid clay coatings show less clear lamination; PPL. D-G) Soil profile A58, sector SC2 (San Colombano relief); D) concave-upwards $\mathrm{S}_{0-1}$ surface truncates the sandy alluvial facies of CPS. Above it, a sequence of BC to Bw reddish soil horizons (dashed lines: gradual boundaries) is observed in the colluvial infilling. E) Two generations of textural pedofeatures: 1) orange, weakly laminated 
and limpid clay coatings; 2) compound pedofeature of laminated coatings of brown clays and silt. CH = channel; g = grain; PPL. F) Lithorelict made of weathered silty sand; PPL. G) Detail of the bedded sands of CPS. Fe-oxides precipitation occurred along the coarser-grained laminas. Scale bars: 1 mm.

\subsubsection{Soils in SC1, the uppermost fault block}

Profile A1 is located on the flat surface that characterizes the top of the most elevated morphological sector SC1 (Fig. 1B). The profile crosses the L2 loess, aggraded at $\mathrm{S}_{1-1}$ on CPS alluvial sediments, that in turn truncate the marine substratum at S0 (Fig. 3). Profile A1 consists of two superposed soils. The shallower soil developed from the sandy silt of L2 (Fig. 4) and has a neutral pH (Fig. 3B; Table 2); it is truncated on top by land reworking (Fig. 8A). Two distinct Bt horizons (Bt and Btx) crop out. Laboratory analyses and micromorphology show that weathering increases from the ground surface towards the horizon Btx; the b-fabric is crystallitic in Bt, while striated, associated to a prismatic microstructure in Btx. The horizon Btx is marked by well-expressed vertic features (Duchaufour, 1995) such as slickensides and argilloturbation. The frequent voids are coated by a compound layering of dusty and limpid, orange cc (Fig. 8D). An older generation of brownish laminated $\mathrm{cc}$ is degenerated and widely assimilated in the groundmass (Fig. 8E) in the form of papules. External hypocoatings by precipitation of Fe-Mn oxides and depletion along the most conductive voids followed (Fig. 8D). Frequent rounded, sub-cm-sized and soft Fe-Mn nodules and concretions between aggregates, characterize the lowermost $20 \mathrm{~cm}$ of Btx, down to the surface $\mathrm{S}_{1-1}$ (Fig. 8A).

Increasing sand fractions, contrasting reddish and pale colours of the soil matrix and a slightly alkaline pH have been observed below $\mathrm{S}_{1}$ ${ }_{1}$. The main macro-feature is the occurrence of a horizon marked by common $\mathrm{cm}$-sized rounded Fe-Mn nodules and decimetre-sized calcareous crusts and nodules (2Bck, Figs. 3, 8B, C); the latter incorporate both hydromorphic sandy soil matrix and the Fe-Mn nodules. At least two generations of illuvial coatings have been observed in the horizon $2 \mathrm{Bck}$, though hardly distinguishable due to the intense oxides impregnation of the soil matrix. The first laminated coating of brownish, dusty clay is followed by laminated coatings of more limpid, orange clays with low birefringence. Illuvial clays get abundant in the horizon $2 \mathrm{Btgc}$, where they appear often as thick intergranular coatings, not in contact with voids. As in the horizons above, these textural pedofeatures underwent dense impregnation by Fe-Mn oxides, resulting in the yellow to brown segregations in the matrix of horizon $2 \mathrm{Btgc}$ (Fig. $8 \mathrm{~F}$ ). In the horizons just below $\mathrm{S}_{1-1}$, a younger generation of orange, limpid cc cross-cuts the older ones within voids; it shows comparable colour, texture, interference colours and extinction pattern of the last illuviation phase observed in the uppermost soil (horizons Bt and Btx in L2). The lowermost horizon of the A1 profile (2CB) reaches down to the S0 surface; it is characterized by laminated coatings of dusty clays of low birefringence, pellicular microstructure and dominant pale colours of the groundmass. All the pedofeatures are affected by late depletion (Fig. 8G).

Interpretation

The generations, thickness and degree of impregnation and preservation of the illuvial pedofeatures described in the CPS, have not been found in L2 loess. They testify that at least two older phases of clay translocation took place on top of CPS before the deposition of the loess. Moreover, the marked Fe-oxides segregation in $2 \mathrm{Btgc}$, the abundant redox depletion pedofeatures of $2 \mathrm{BC}$ indicate strong hydromorphism, probably enhanced by a climate warmer and wetter than at present and favoured by the proximity of a basal aquiclude (i.e. the marine clays and marls below S0 surface; Fig. 3) acting as a barrier of the infiltration-water. These paleohydromorphic pedofeatures suggest that a different geomorphological setting pre-existed at A1 site, since the present-day conditions (flat surface bounded by steep hillslopes) do not favour water-logging and stagnation. Above $S_{1-1}$, the typical unimodal grain-size distribution of the sediments (Fig. 4) and the different generations of cc, confirm that a new pedogenetic cycle took place at A1 site after the deposition of at least 1.5 $\mathrm{m}$ of loess deposits, arguably during interglacial/interstadial conditions.

Hence, the described polygenetic soils (sensu Bos and Sevink, 1975) represent two distinct phases of landscape stabilization, characterized by a progressive lowering of water-logging related processes up to the present-day top. $S_{1-1}$, i.e. the base of L2 loess, coincides here with the buried morphological surface of stabilization and first pedogenesis of CPS. Cross-cut relations between illuvial textural pedofeatures and depletion pedofeatures suggest that water saturation took place in the profile after the translocation of clays. The vertic behaviour of the loess, the frequently observed crystallitic b-fabrics (Table 3), the occurrence of sub-rounded $\mathrm{CaCO}_{3}$ throughout the soil and the overall subalkaline $\mathrm{pH}$ of the lower portion of the profile, are consistent with the potential influence of the marine clays, limestones and marls a few metres below the ground surface. 

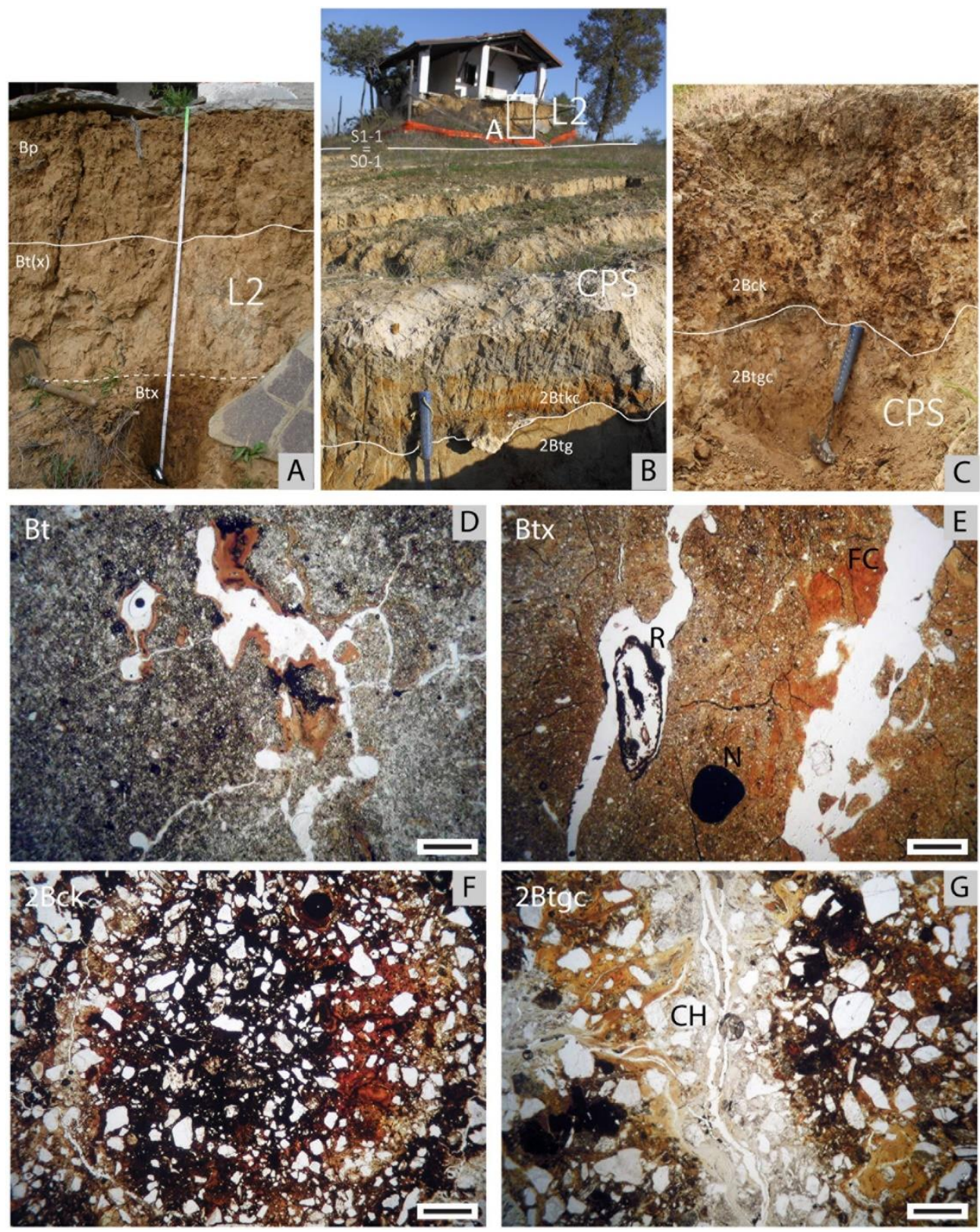

Fig. 8. Soil profile A1, sector SC1 (San Colombano hill). A) Topmost horizons of A1 developed on loess L2. B) View of the A1 site. C) Detail of the 2Bck horizon, located below S0-1 planation surface and above hy- dromorphic medium-grained alluvial sands of CPS. D-G) Micromorphological features; plane polarized light PPL; crossed polarized light XPL: D) Bt horizon. Laminated coat- ings of alternate dusty/limpid orange clays within channels and chambers; late Fe-Mn hypocoating and depletion (globular- shaped, paler zones around voids); PPL. E) Vertic pedofeatures in horizon Btx. FC=fragments of reddish clay coatings, reworked by pedoturbation (slickenside) and cut by a sub-vertical plane of $1 \mathrm{~mm}$ opening. $\mathrm{R}=$ section of a mm-sized brown root fragment. $\mathrm{N}=$ typic, rounded nodule of Fe-Mn oxides with sharp border; PPL. F) Concentric Fe-Mn nodule in 2Bck horizon showing regular outline and high contrast with the soil mass. Orange-red clay coatings postdate the formation of the nodule; depletion is the last phase. G) Horizon 2Btgc sampled within the hydromorphic CPS sands; PPL. Depletion is the last pedoge- netic phase, that takes place within the most conductive voids ( $\mathrm{CH}=$ sub-vertical channel). Notice the high contrast between depleted and impregnated areas; PPL. Scale bars: $1 \mathrm{~mm}$.

\subsection{Geopedological features of the Casalpusterlengo relief: CAS sector}

Since relicts of both alluvial and loess facies are preserved on the CAS and ZOR isolated relief sectors more eastwards, a brief description and interpretation of the soil features of A03 are proposed; a comparison with the soil profiles observed at the ZOR sector will follow in the Discussion chapter. The identification of the stratigraphic surfaces (S0 to S2) is based on the correlation proposed in the Stratigraphy chapter. Anyway, a local name is assigned to the surfaces (CAS-SX) to account for their significance of "surfaces equivalent to" the X surfaces identified in the San Colombano area.

Profile A03 has been sampled at the abandoned quarry site on top of Casalpusterlengo relief (CAS; Fig. 1A). The described section, about

$5.5 \mathrm{~m}$ thick, involves, from top, colluvial deposits in the first $45 \mathrm{~cm}$, followed by $1 \mathrm{~m}$-thick loess up to CAS- $\mathrm{S}_{1-1}$ and two underlying sequences of sandy, bedded alluvial deposits separated by CAS-S $\mathrm{S}_{0-1}$ (Fig. 9A); these units correlate to L2, $\mathrm{CPS}_{2}$ and $\mathrm{CPS}_{1}$ in the San Colombano area, respectively; the two lowermost horizons have been dated to the Late Pleistocene (Panzeri et al., 2011) and a correlation 
to the MIS 5 (Lisiecki and Raymo, 2005) is proposed. The profile has abundant clay coatings both on top of the loess (horizon 2Btc) and on top of the alluvial deposits (horizon 2Btg), suggesting the preservation of at least two soils.

The 2Btc horizon of the uppermost soil is characterized by striated to crystallitic b-fabric, channel microstructure, frequent typic FeMn nodules and a very weak impregnation of the groundmass. Three generations of cc are present (Fig. 9B): the first generation consists of juxtaposed compound layers of microlaminated dusty to limpid clay; frequently in contact with the observed voids, it is locally deformed and fragmented. The second generation consists of laminated orange to red pure clay with high birefringence, and locally juxtaposed brown hypocoatings. The third generation comprises pure, typic orange to yellow, nonlaminated cc, locally associated to dark Fe-Mn hypocoatings. The second and third generations are always observed in contact with voids. Rare papules of deformed, red limpid cc have been observed.

The illuvial horizon 3Btg (Fig. 9) below CAS-S ${ }_{1-1}$ shows a different assemblage of cc. Illuvial pedofeatures compose the totality of fine fraction; the dominant cc consists of typic brown-yellow coarse clays with high birefringence. They are often dispersed in the groundmass and covered by a second generation of typic, laminated coatings of dusty to pure clay in contact with voids (Fig. 9C). The latter are subordinate and thinner than the first generation. Rare fragments of reddish-brown typic cc are present.

The lowermost horizon $(4 \mathrm{BCg})$, sampled below $\mathrm{CAS}-\mathrm{S}_{0-1}$, shows rare evidences of weathering. Micropan of brown dusty clay are common; the only observed cc consist of dominant pure, microlaminated orange clays with high birefringence and form common linkcappings. Rare granular infillings of brown silt are present.

Interpretation

The field evidences and the discrimination of different sets of pedofeatures within the described horizons suggest that the remnants of at least three weathering profiles are preserved in the outcrop A03. The weak illuvial pedofeatures observed in 4BCg contrast with the horizons just above, where evidences of weathering are absent. It testifies that soil truncation occurred in correspondence of $\mathrm{CAS}_{-} \mathrm{S}_{0-1}$. The nature of the pedofeatures and the two maxima of illuviation observed above the same boundary, testify that the CAS-S ${ }_{1-1}$ marks the morphological surface of stabilization above which the L2 loess aggraded. The youngest pedological profile, showing the most preserved textural pedofeatures, developed on L2, starting from the new stabilization surface corresponding to the present-day topography. No evidences of erosion at CAS-S $\mathrm{S}_{1-1}$ can be deduced from the available data. The present interpretation is in accordance to the field analyses briefly presented in Panzeri et al. (2011), that suggested the polycyclic pedogenetic history of the Casalpusterlengo relic relief.

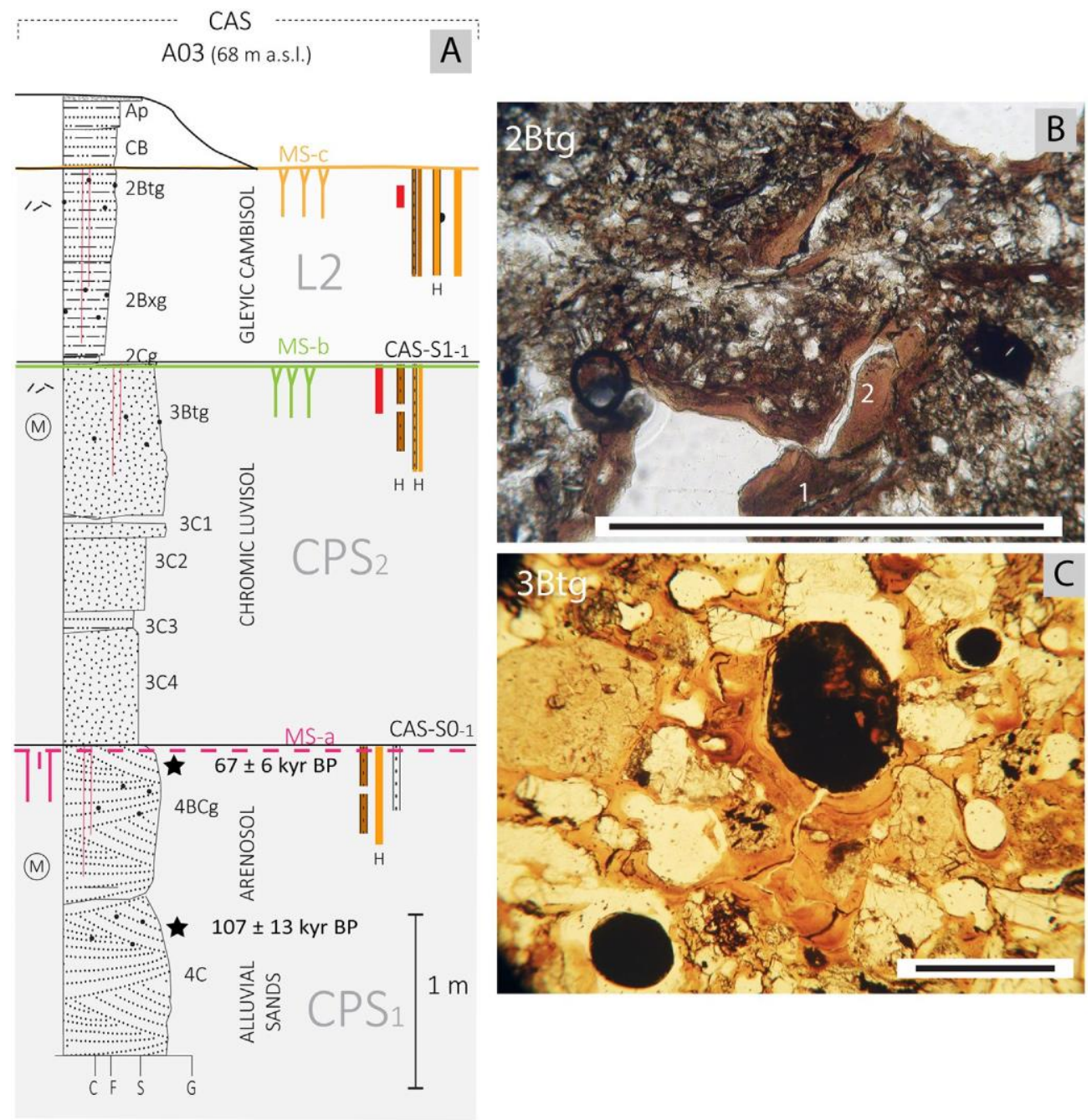


Fig. 9. A) Log of the pedostratigraphic profile A03, geomorphological sector CAS (Casalpusterlengo hill). Legend as in Fig. 3. B-C) Micromorphological features of A03; B) Two generations of coatings; 1: dusty brown silty clays, 2: compound layer of weakly laminated coatings of limpid and dusty orange clays. Porphyric close-spaced c/f relative distribution; PPL. C) Pervasive clay coatings in the intergranular voids of horizon $3 \mathrm{Btg}$. The 1 st generation consists of weakly laminated coatings of brown, dusty clays; the 2nd is more limpid, orange, in continuity with voids; PPL.

\section{Discussion: soil development, geological boundaries and landscape evolution}

The pedo-stratigraphic analyses highlighted that i) the most recent weathered loess (L2 unit, LGM loess) covers the studied reliefs and has not been detected in the close surrounding plain, probably related to the latest Pleistocene depositional dynamics that involved the alluvial plain environment at the PML sectors; ii) sectors SC4 and ZOR (Cremaschi, 1987) host two preserved loess units, the oldest one (L1 unit) ascribed to the pre-LGM, the youngest (L2 unit) to the LGM acme. Their grain-size distributions fit well with the curves of Po Plain loess proposed by Cremaschi (2004, 1987, Fig. 4); iii) during the Late Pleistocene alternating phases of sediment aggradation, stabilization and pedogenesis, erosion and re-deposition of soil profiles occurred. The strong landscape instability which characterized these reliefs during the Late Pleistocene relates to uplift and faulting at the SC hill, CAS and ZOR sectors and to the alluvial and glaciofluvial erosional-depositional history at the PML sites surrounding the hills.

A complete polygenetic pedo-sequence (compound geosols as reported by Catt, 1998) of the San Colombano hill is preserved in the ABF profile of the lowermost hill morphological sector SC4, where three superposed in situ soils have been recognized (Fig. 3). This profile permits to define three distinct morphological surfaces of stabilization (i.e. biostasy phases in which pedogenesis played a major role; Erhart, 1967; 'MS' hereafter), named MS-a, MS-b and MS-c in order of younging (Figs. 3, 10), which could be recognized and correlated through the different sectors of the study area. The MS-a and MS-b are associated with soils that can be considered as paleosols according to the Paleopedology Glossary (INQUA WG, 1995), since they date to Pleistocene ages and exhibit evidences of pedogenesis referred to climatic conditions different from the present. Hence, as soils represent reliable markers of a stable topography, MS-a and MS$\mathrm{b}$ correspond to the preserved relicts of paleo-topographic surfaces at ABF and at the other sites where L1 and L2 loess aggraded (i.e. physically relating to $S_{0-1}$ and $S_{1-1}$ stratigraphic boundaries, respectively). MS-c represents the stable sectors of the late post-glacial Holocene to present-day topography which are far away from the erosion-aggradation dynamics of the alluvial valleys and of the relief slopes (Figs. 2, 3). The correlation of the MS surfaces was demonstrated by integrating the sedimentological, stratigraphic, geomorphological and structural observations collected in the study area (details also in Zuffetti et al., 2018) with the geopedological keyfeatures described in the previous paragraphs (in situ buried paleosols, reworked soils, generations of illuvial coatings, coarse-grained infillings). The pedostratigraphic scheme of Fig. 3 helps in clarifying the composite nature of the stratigraphic boundaries (S) in relation to the detected, soil-marked, morphological surfaces (MS) and hence to unravel the increments of the morpho-tectonic and depositional evolution of the relief. The integrated evolution scheme is presented in Fig. 10, focussing on the sedimentary, tectonic and pedogenetic processes which led to the origin of the different types of "S" stratigraphic surfaces and of the related "MS", morphological surfaces, during the Late Quaternary. According to the pedogenetic features and the degree of development of the B horizons composing the pedosedimentary sequences of the studied reliefs, we tentatively classified the soils as Luvisols (mainly related to MS-a and MS-b surfaces) and Cambisols (mainly associated to MS-c; WRB IUSS Working Group, 2015). Further subdivisions, depending on reddening rating and the abundance of hydromorphic features, are proposed in Fig. 3.

\subsection{Morphological surface MS-a}

Paleosol associated with MS-a involved the alluvial sequences of $\mathrm{CPS}_{1}$ (ABF profile) and the correlative units in the eastern study area (A03 profile; Figs. 9 and 10). It is characterized by evident illuviation and soil structure at the macroscale and dominant red colours of the soil mass. Illuvial coatings are the dominant pedofeatures, and consist of at least four generations of cc (ABF). Among them, only the two most ancient phases are preserved in A03, testifying that MS-a has been truncated at CAS-S $\mathrm{S}_{0-1}$ (Figs. 9, 10). We assume that erosion occurred at the alluvial plain level, before the subsequent uplift of the Casalpusterlengo relief, since $2 \mathrm{~m}$ of alluvial sequences of Late Pleistocene age are stacked above CAS- $\mathrm{S}_{0-1}$. A deep paleosol developed on truncated alluvial sequences was described by Cremaschi (1987) also at the Zorlesco hill (Fig. 1). We tentatively propose a correlation of the paleosol underlying MS-a with the lowermost one described at the Zorlesco relief, even if an older age of the latter cannot to be excluded.

Excluding SC4 (represented by ABF profile), the paleo-morphological surface MS-a has not been detected on the other uplifted sectors of the San Colombano hill. Some relict pedofeatures preserved at the base of A60 (SC2 sector, Fig. 3), which can hardly be linked to the more recent preserved weathering profile, and the pedorelicts described in the colluvial deposits of A58, A44, A53 sites, suggest that a soil comparable to that underlying MS-a was eroded at least from some of the uplifted sectors. The results testify that, while no substantial erosion of MS-a occurred in SC4, a deep truncation of the same stabilization surface took place in the uplifted sectors. Hence, the $\mathrm{S}_{0-1}$ stratigraphic surface corresponds to an erosional surface in SC1, SC2, SC3 sectors, while it represents the loess aggradation surface in SC4.

The mentioned age determinations of $\mathrm{CPS}_{1}$ at the base of ABF and A03 profiles are close to MIS 5 (Figs. 3, 9). The youngest of these age determinations at A03 profile (67 \pm 6 kyr BP; Fig. 3) does not match perfectly this MIS. However, taking into account the range of uncertainty related to OSL determinations (Panzeri et al., 2011), we propose to associate the MS-a stabilization to the MIS5a interstadial, because of the typical interglacial features observed on top of the described CPS $_{1}$ sediments and the presence of mildly weathered loess and/or glacio-fluvial sediments just above. Furthermore, the degree of weathering and the stratigraphic position of MS-a look to be quite similar to the lowermost paleosol described by Zerboni et al. (2014) on the relic relief of Monte Netto, in the northern Po Plain (Fig. 1A). To the South of the Basin, MS-a assimilates the buried paleosurfaces underlying the loess cover at the N-Apennine fringe and dated on the truncated top of alluvial terraces, as described by Cremaschi et al. (2015), Martini et al. (2001), and Maestrelli et al. (2018). 


\subsection{Morphological surface MS-b}

Paleosol associated with MS-b was observed in all the studied profiles (Figs. 3, 10). It is the most recent buried soil found on CPS and correlative units in the study area. The paleosol is characterized by at least three B horizons (profiles A44, A60, A58, Fig. 3) and reddishbrown colours of the soil mass. The numerous evidences of paleohydromorphism (dense mass impregnations in A1, A44, degraded at present; cm-sized Fe-Mn nodules in A1, ABF; clay intercalations in ABF; Fig. 3) suggest that MS-b became stable under interglacial conditions. The results show that MS-b is best preserved on the SC4 sector, while it was weakly reworked on the rest of the San Colombano hill.

To the east, we correlated MS-b with the top of the lowermost loess of the profile described by Cremaschi (1987) on the Zorlesco relief. Here, as in ABF, the absence of evident truncations of MS-b records that since the loess deposition, SC4 and ZOR morphological sectors were no longer influenced by fluvial erosion or deposition. Plausibly, at that time they already represented tectonic-induced morphological paleo-highs isolated in the plain, thus offering the condition for trapping and preservation of aeolian sediments from fluvial erosion at their top surfaces.

Geomorphological and geopedological evidences confirm that MS-b marks a flat, sub-horizontal stratigraphic surface $\left(\mathrm{S}_{0-1}\right)$ at $\mathrm{SC} 1$, at present elevated about $140 \mathrm{~m}$ a.s.l. and covered by the L2 loess (Fig. 3). We interpret $\mathrm{S}_{0-1}$ as the uplifted remnants of the alluvial planation surface between $\mathrm{CPS}_{1}$ and $\mathrm{CPS}_{2}$ sub-Synthems, that developed where rivers were not able to aggrade due to subtle uplift (Holbrook and Schumm, 1999). Also, paleohydromorphic evidences suggest that the topographic setting should have favoured water-logging and stagnation at the site of A1 profile before its uplift and incorporation in SC1 morpho-tectonic sector. Hence, the erosional top of the SC1 sector represents an erosional alluvial terrace, plausibly linked with the deposition of the CPS2 sub-Synthem, which was progressively uplifted and stabilized during Late Pleistocene, before the LGM. It derives that $\mathrm{S}_{0-1}$, which soles the buried MS-b surface at SC1, constitutes a key stratigraphic boundary. This interpretation fits with the discussion of comparable morpho-tectonic features described in other sectors of the Apennines (Basili et al., 1999; Coltorti and Pieruccini, 2000).

The age determinations on the alluvial sediments framing the L1 loess, its stratigraphic position and paleo-pedological features indicate that L1 aggraded on top of the $\mathrm{CPS}_{1}$ sediments (Figs. 2, 3 and 10), during the acme of the glacial cycle corresponding to MIS4, which corresponds to the $\mathrm{CPS}_{2}$ deposits in the area. According to this interpretation, weathering at MS-b mostly occurred during the subsequent interglacial MIS 3, in accordance to the general model that loess deposition is ascribed to the colder and dryer periods of glacial acme, while soil formation prevails during more humid interglacial (Kemp, 2001; Pye, 1995). The attribution to this interglacial fits with the interpretation, based on comparable paleopedological indicators and micromorphological features, carried out on the paleosols on top of older glaciofluvial terraces in the northern Po Plain (Cremaschi, 1987; Kühn et al., 2006; Terhorst and Ottner, 2003; Zuccoli, 1997). The pedofeatures of the MS-b paleosols in the study area found a good correlation to the dated MIS 3 paleosols described on the loess covers both at the northern (Ferraro, 2009; Zerboni et al., 2014) and southern (Cremaschi et al., 2015; Maestrelli et al., 2018) fringes of the Po Plain. The well-expressed paleohydromorphic pedofeatures and the stratigraphic position of MS-b are comparable to the weathering profiles of the Late Pleistocene uplifted remnants of loess, described on the top of the Romanengo relic relief and post-dating the deposition of the Middle-Late Pleistocene alluvial units (Bresciani and Perotti, 2014). Moreover, the evidences and chronology of the N-Apenninerelated tectonics controlling $\mathrm{CPS}_{2}$ deposition in the study area, fit well with the works of Frigerio et al. (2017) and Maestrelli et al. (2018). They both suggest active incremental uplift, due to thrusting reactivation, in the last $80-60 \mathrm{kyr}$ at the Monferrato and Pedeapennine buried thrust fronts, respectively.

\subsection{Morphological surface MS-c}

Soils associated with MS-c always formed above the L2 loess (LGM) deposited after the glacio-fluvial to alluvial INS and VIL units (Fig. 2). L2 is bounded on top by the topographic surface or it is covered by the colluvial deposits of MLS (ABF, A44 profile; correlative CAS-S-2, A3 profile). The soil profile consists of 2 to 3 B horizons, at places showing fragipan features (A1, A44, A53, A03; Fig. 3; Soil Survey Staff, 2014), without evidences of deep truncation. The oldest generation of cc is always fragmented, while the last, limpid one is always in contact with voids, testifying the recent age and stable condition of the related soil forming processes. MS-c related soils are often superposed to the older (paleo-) pedogenic cycles in the lower levels of the studied profiles, giving rise to complex paleo-soil profiles (sensu Duchaufour, 1995). The moderate pedogenesis which developed from MS-c does not show strong redoximorphic pedofeatures, except for ABF profile, where the presence of the well-expressed paleosol buried under L2 could have acted as a barrier for water infiltration.

The stratigraphic position and the moderate pedogenesis fit with the attribution of MS-c related soils to the Post-LGM, last interglacial climatic stabilization. It agrees with the interpretation of Cremaschi (1987) at the ZOR and CAS reliefs, and with the age attribution of the topmost loess covers on the northernmost relic reliefs of the Po Plain (Cremaschi, 1987; Livio et al., 2012; Zerboni et al., 2014). At the Apennine fringe, comparable soils have been preserved in the western part of the southern Po Plain (Busacca and Cremaschi, 1998), while no evidences of correlative profiles nor LGM loess have been found to the east (Cremaschi et al., 2015).

\subsection{Colluvial deposits}

The colluvial deposits observed above the surfaces $S_{0-1}$ and $S_{1-1}$ (Figs. 3 and 10) occur in different stratigraphic and geomorphic positions but show comparable geopedological features. They all consist of stratified, heterometric, sandy- to silty-grained sediments. They contain common subangular pedorelicts, that are more weathered than the colluvial groundmass and show comparable features of both MS-a- and MS-b-related paleosols. The thick colluvial infilling of the paleo-valley at A58 site (SC2; Figs. 3 and 10) suggests that consistent colluviation took place after valley incision and abandonment, probably enhanced by Late Pleistocene syn-tectonic drainage 
diversions (Zuffetti et al., 2018). The observed evidences of pedogenesis support the earlier formation of this colluvium than the other ones in A44, A60, A53 sites (Fig. 10). The latter testify that soil redeposition occurred along N-dipping slopes, and sourced from weathered alluvial-loess-paleosol sequences located in more elevated positions. Their petrographic composition (Fig. 3) suggests a contribution of both INS and CPS as source sediments. Comparable colluvial units cover both MS-b (A44, A60 sites) and the perched INS alluvial terrace (A53 site); their wedges locate close to the fault scarps (Figs. 1 and 3), at a lower height than the SC1 uppermost fault block, and rework relicts of both MS-a and MS-b, hence we propose that several colluviation phases occurred in the Latest Pleistocene, even after MIS 3 interglacial (i.e. after the stabilization and pedogenesis at MS-b paleo-landsurface), at least up to the early LGM. Moreover, since their pedogenesis develops in continuity with the pedogenetic cycle of the overlying L2 loess deposits and their stratigraphy indicates repetitive phases of aggradation during slope instability, we propose that they took place during repetitive discrete events, i.e. during increments of tectonic displacement along the main fault scarps (Amit et al., 1995 and references within). In this sense, colluvial pedofeatures represent key stratigraphic features both to describe the paleo-topography (i.e. MS-b at A44 and A60 sites, or the top of the uplifted INS terrace at A53; Fig. 3) and to unravel the chronology of tectonic instability from the buried pedostratigraphic record.

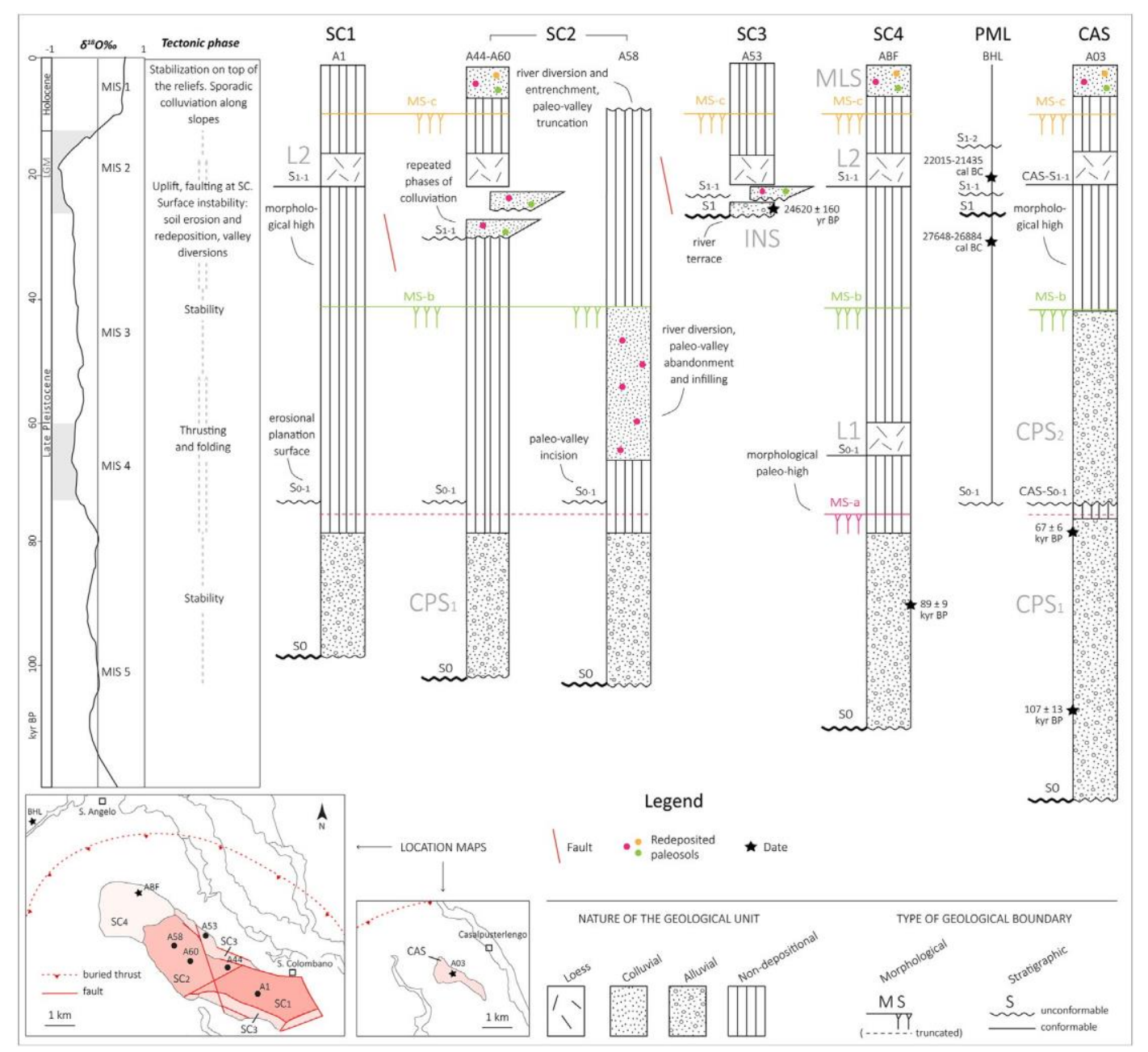

Fig. 10. Late Pleistocene chronology of the main depositional, pedogenetic and tectonic phases at the origin of the landscape of the study area. Surfaces of morphological stabilization (MS) mainly formed at sites and during times of depositional/tectonic stability, while soil erosion (unconformable S) and redeposition increased during active folding and/or faulting. MIS: marine isotope stages (modified after Martinson et al., 1987). Age determinations: *) from Bersezio et al. (2004); **) from Panzeri et al. (2011).

\subsection{Landscape incremental evolution}

The combination of the discussed datasets allowed proposing the Late Pleistocene, climatic- and tectonic-driven incremental evolution at the origin of the present-day landscape of the Lower Po Plain (Fig. 10):

1) During the Late Pleistocene, the distal glacio-fluvial and alluvial Cascina Parina Synthem and its correlative sequences exposed at the Casalpusterlengo (CAS) and Zorlesco (ZOR) areas were deposited. A phase of interglacial stability and humid conditions (late MIS 5) determined the formation of Chromic Luvisols on the stable surface MS-a, which was subsequently redistributed by faulting and uplift and widely eroded. Remnants of MS-a and related paleosols (including the redeposited pedorelicts) are now poorly preserved in the study area. 
2) The composite surface $S_{0-1}$ shaped a new landscape, mostly by erosional truncation, predating the deposition of CPS $\mathrm{S}_{2}$ sub-Synthem (ca. 67-27 kyr based on OSL and AMS radiocarbon dates). This surface testifies a phase of differential uplift of the San Colombano area, from which the mentioned morpho-tectonic sectors started to differentiate and evolve separately. This tectonic evidence suggests a late thrusting increment along the Sant'Angelo Lodigiano frontal thrust (Fig. 1), which finds a good chronological correspondence with the thrusting stages proposed for the pedeapennine border by Frigerio et al. (2017) and Maestrelli et al. (2018). Uplift was more pronounced in the western sectors (ABF site, paleo-high SC4), where MS-a was preserved being subtracted from terracing. To the east, valley incision (A58 site, SC2 sector; Fig. 10) accompanied the increase in relief energy, i.e. the first origin of the San Colombano relief and of its former drainage network, while generalized erosion took place in the subtly uplifting sectors (A1 site). In the meanwhile, alluvial and glacio-fluvial terracing and deposition took place in the surrounding subsiding sectors, whose elevation corresponded to the base-level for alluvial deposition at that time. As a result, the planation surface $\mathrm{S}_{0-1}$ was cut at SC1, while terracing and deposition of $\mathrm{CPS}_{2}$ sequences occurred at Casalpusterlengo (CAS, Fig. 10) and to the N of the SC4 sector (see Figs. 1, 2 and BHL site in Fig. 10). At the glacial acme of MIS 4, corresponding to the late deposition increments of the glacio-fluvial $\mathrm{CPS}_{2}$ sub-Synthem, the late glacial loess L1 aggraded on the stable paleo-highs (sector SC4 and ZOR).

3) During MIS 3 interglacial, Chromic Luvisols formed on the gentle topography, marked by the stabilization surface MS-b, under humid and warm climate which was responsible for highly developed paleo-hydromorphic pedofeatures. Pedogenesis involved the truncated $\mathrm{CPS}_{1}-\mathrm{CPS}_{2}$ and the L1 loess at different sites (Figs. 10 and 3), documenting the concurrent tectonic stability at this time.

4) The beginning of the last glacial phase corresponded to the deposition of the glacio-fluvial Invernino Synthem, the alluvial Villanterio unit and the correlative LGM depositional systems on the alluvial plain surrounding the still smooth reliefs. Alluvial terracing took place along their flanks giving origin to the composite erosional surface S1.

5) The subsequent increment of uplift and dissection affected the eastern sectors of the San Colombano hill (SC1 and SC2) along conjugate faults (Figs. 1 and 10). At this time the inversion of the relief started, with the uplift of the oldest INS terraces at the northern SC3 sector. The paleo-topographic stable surface MS-b was dissected and covered by colluvial wedges, sourced from the now most elevated sector SC1. These wedges were deposited along the faulted flanks of SC1 towards the intermediate fault blocks SC2. SC4, CAS and ZOR sectors lack INS deposits, testifying their definitive elevation above the surrounding alluvial plain during the LGM. The ongoing uplift, accompanied by dissection of the San Colombano relief along a WNW-ESE directed transtensive fault system, gave origin to the northern and southern fault blocks SC3. Also at these sites, colluvial wedges containing clasts and pedorelicts of redeposited paleosols covered, by means of the depositional surface $\mathrm{S}_{1-1}$, the dissected INS terrace at SC3 (A53 site). A concurrent tectonic-driven reorganization of the drainage pattern took place along the San Colombano hill (Zuffetti et al., 2018). This tectonic increment was characterized by erosion and widespread deposition of colluvial deposits at the base of the fault scarps.

6) The L2 loess (MIS 2, acme of LGM), spreading from the North (compare with Cremaschi et al., 2015 and references therein), covered the composite $S_{1-1}$ surface and the colluvial wedges above it, contributing to shape the late LGM paleo-landscape of the San Colombano, Zorlesco and Casalpusterlengo reliefs. No loess deposits could reach the southern SC3 fault block, because it was sheltered by the most elevated SC1 and SC2 fault blocks to the North.

7) After the LGM acme, extended interglacial climate stability and stabilization of the topography concurred to the origin of the morphological surface MS-c, which is associated to a moderate pedogenesis. Prolonged stream incision on the San Colombano hill cut the traces of the former paleo-hydrography (as the mentioned gully around A58 site in SC2).

8) A latest uplift stage, plausibly of regional extent, is the latest tectonic increment recorded by the post-glacial (latest Pleistocene to Holocene) colluvial deposits of the Monteleone Synthem. They occur within the incised valleys and along the slopes of the isolated hills and blanket the terrace scarps of the coeval Po Synthem. The regional entrenchment of the major drainage network, including the Po, Lambro and Adda rivers in the study area, occurred at the same time. It gave origin to the present-day landscape, that is formed by the terraced alluvial plain above which the poly-history scattered hills here discussed are elevated.

\section{Conclusions}

The Late Pleistocene depositional, morphological and soil forming processes at the Po Plain-Northern Apennine border in correspondence of the San Colombano, Casalpusterlengo and Zorlesco isolated reliefs were controlled by the complex interference between incremental tectonic phases, driving landscape erosion and stabilization, and glacial-interglacial cycles, driving soil formation and the evolution of glacio-fluvial and alluvial depositional systems. At least three main pedogenetic cycles were associated to three morphological (paleo-) surfaces of landscape stabilization (i.e. morphological surfaces MS-a, MS-b, MS-c) during the Late Pleistocene. Paleosols occur both as in situ and as redeposited entities; they are differently preserved at different geomorphic positions corresponding to the morpho-tectonic sectors that we identified in the isolated reliefs and adjacent plain main level. In such a setting paleosols represent a valid geomorphic and stratigraphic marker, which contributes to i) correlate the morphological surfaces (the basic landscape and paleolandscape units), ii) to recognize the stable surfaces (areas of superimposed pedogenetic cycles) from the unstable erosional and/or aggradational surfaces and stratigraphic boundaries (areas of fault- vs. alluvial-controlled erosion and deposition), iii) to constrain the Late Pleistocene-Holocene geological evolution of the southernmost Po Plain of Lombardy. Age determinations allowed to constrain the timing of some key pedo-stratigraphic intervals, to refine the chronology of the pedological evolution and to assist correlations throughout the study area. Hence, also the formation chronology of erosional, aggradational and stabilization geological boundaries has been clarified. The multi-approach study allowed to discuss the chronology and location of tectonic, erosional and depositional events vs. the sites and times of landform stabilization and pedogenesis, providing new constraints to describe the incremental, tectonic-climatic driven evolution of the landscape of the Po Plain-Apennine border in Lombardy.

\section{Acknowledgements}


We would like to thank Chiara Compostella and Elena S. Ferrari for the assistance in sample preparation and chemical analyses. We also thank Prof. A. Amorosi and an anonymous Reviewer for their accurate reviews. Funding for field-work, thin sections preparation and laboratory analyses was provided to RB and LT. The paper is a part of the PhD Thesis of CZ, under the supervision of RB.

\section{Declarations of interest}

None.

\section{References}

Aigner, T., Heinz, J., Hornung, J., Aspiron, U., 1999. A hierarchical process-approach to reservoir heterogeneity: examples from outcrop analogues. Bull. Cent. Rech. Elf Explor. Prod. 22, 1-11.

Alfano, L., Mancuso, M., 1996. Sull'applicabilità del metodo dipolo-polare continuo nelle ricerche idriche a media profondità in aree di pianura. Acque Sotterranee 13, 61-71.

Amit, R., Harrison, J.B.J., Enzel, Y., 1995. Use of soils and colluvial deposits in analyzing tectonic events - the southern Arava Rift, Israel. Geomorphology 12, 91-107. https:// doi.org/10.1016/0169-555X(94)00081-2.

Amorosi, A., Colalongo, M., Fiorini, F., Fusco, F., Pasini, G., Vaiani, S.C., Sarti, G., 2004.

Palaeogeographic and palaeoclimatic evolution of the Po Plain from 150-ky core records. Glob. Planet. Chang. 40, 55-78. https://doi.org/10.1016/S0921-8181(03) 00098-5.

Amorosi, A., Pavesi, M., Ricci Lucchi, M., Sarti, G., Piccin, A., 2008. Climatic signature of cyclic fluvial architecture from the Quaternary of the central Po Plain, Italy. Sediment. Geol. 209, 58-68. https://doi.org/10.1016/j.sedgeo.2008.06.010.

Amorosi, A., Bruno, L., Cleveland, D.M., Morelli, A., Hong, W., 2017. Paleosols and as- sociated channel-belt sand bodies from a continuously subsiding late quaternary system (Po basin, Italy): new insights into continental sequence stratigraphy. Bull. Geol. Soc. Am. 129, 449-463. https://doi.org/10.1130/B31575.1.

Anfossi, G., Desio, A., Gelati, R., Laureri, S., Petrucci, F., Venzo, S., 1971. Note illustrative della Carta Geologica d'Italia. F. ${ }^{\circ 60}$. (Piacenza).

Argnani, A., Barbacini, G., Bernini, M., Camurri, F., Ghielmi, M., Papani, G., Rizzini, F., Rogledi, S., Torelli, L., 2003. Gravity tectonics driven by Quaternary uplift in the Northern Apennines: insights from the La Spezia-Reggio Emilia geo-transect. Quat. Int. 101-102, 13-26. https://doi.org/10.1016/S1040-6182(02)00088-5.

Ariati, L., Cotta Ramusino, S., Peloso, L.G., 1988. La struttura del Colle di San Colombano al Lambro: riflessi idrogeologici e caratteristiche chimiche della falda freatica. In: Casati, P. (Ed.), Acque Sotterranee Di Lombardia. Dipartimento Scienze della terra e CNR - Centro di Studio per la stratigrafia e petrografia delle Alpi Centrali, Milano, pp. 97-115.

ARPA Lombardia, 2016. Sintesi meteo-climatica 2016 [WWW Document]. URL. http:// www.arpalombardia.it/siti/arpalombardia/meteo/download/Documents/ Sintesimeteo-climatica2016.pdf.

Baio, M., Bersezio, R., Bini, A., 2004. Assetto geologico della successione quaternaria nel sottosuolo tra Melegnano e Piacenza. Quaternario Ital. J. Quat. Sci. 17, $355-359$.

Basili, R., Galadini, F., Messina, P., 1999. The application of palaeolandsurface analysis to the study of recent tectonics in central Italy. Geol. Soc. Lond. Spec. Publ. 162, 109-117. https://doi.org/10.1144/GSL.SP.1999.162.01.09.

Benedetti, L.C., Tapponnier, P., Gaudemer, Y., Manighetti, I., 2003. Geomorphic evidence for an emergent active thrust along the edge of the Po Plain: the Broni-Stradella fault. J. Geophys. Res. 108, 2238. https://doi.org/10.1029/2001JB001546.

Bersezio, R., 1986. Studio fotogeologico e geofisico per la ricostruzione dell'andamento degli antichi alvei: prima ricostruzione dei paleoalvei della Pianura tra Adda e Ticino. In: Studi Idrogeologici Sulla Pianura Padana. CLUP, Milano, pp. 3.1-3.25.

Bersezio, R., Pavia, F., Baio, M., Bini, A., Felletti, F., Rodondi, C., 2004. Aquifer archi- tecture of the Quaternary alluvial succession of the Southern Lambro Basin (Lombardy Italy). Ital. J. Quat. Sci. 17, 361-378.

Bersezio, R., Cavalli, E., Cantone, M., 2010. Aquifer building and Apennine tectonics in a Quaternary foreland: the southernmost Lodi plain of Lombardy. Memorie Descrittive Carta Geolog. Ital XC, 21-30.

Bersezio, R., Zuffetti, C., Cavalli, E., Baio, M., Cantone, M., Inzoli, S., Pavia, F., Rigato, V., Rusnighi, Y., Rodondi, C., Sozzi, S., 2016. The Quaternary N-Apennine tectonics re- corded in the Po Basin: stratigraphic and geomorphological evidences along a N-S traverse in Lombardy (Italy). Geophys. Res. Abstr. 18.

Bertotti, G., Capozzi, R., Picotti, V., 1997. Extension controls Quaternary tectonics, geo- morphology and sedimentation of the N-Apennines foothills and adjacent Po Plain (Italy). Tectonics 282, 291-301.

Bigi, G., Cosentino, D., Parotto, M., Sartori, D., Scandone, P., 1990. Structural Model of Italy. Progett. Final. Geodin. CNR.

Bini, A., Sciunnach, D., Bersezio, R., Scardia, G., Tomasi, F., 2014. Note illustrative della Carta Geologica d'Italia alla scala 1:50.000. Foglio 96 - Seregno. ISPRA.

Bini, A., Baio, M., Violanti, D., Martinetto, E., 2016. Nuovi dati da sondaggi provenienti dai dintorni di San Colombano al Lambro e dalla Pianura Padana a Est di Milano: analisi litostratigrafica, composizionale e micropaleontologica. Geol. Insubrica 12.

Blum, M.D., Price, D.M., 1998. Quaternary alluvial plain construction in response to in- teracting glacio-eustatic and climatic controls, Texas Gulf Coastal Plain. In: Shanley, K.W., J, M.P. (Eds.), Relative Role of Eustasy, Climate, and Tectonism in Continental Rocks. SEPM Spec. Publ., pp. 31-48.

Boccaletti, M., Corti, G., Martelli, L., 2011. Recent and active tectonics of the external zone of the Northern Apennines (Italy). Int. J. Earth Sci. 100, 1331-1348. https://doi. org/10.1007/s00531-010-0545-y.

Boni, A., 1967. Note illustrative della Carta Geologica d'Italia. F. ${ }^{\circ 59}$. (Pavia).

Boni, A., Boni, P., Peloso, G.F., Gervasoni, S., 1981. Dati sulla neotettonica del Foglio Pavia (59) e di parte dei Fogli Voghera (71) e Alessandria (70). CNR, Progetto Finalizzato Geodinamica. Sottoprogetto Neotettonica, Napoli, pp. 1199-1244.

Bos, R.H.G., Sevink, J., 1975. Introduction of gradational and pedomorphic features in descriptions of soils. Eur. J. Soil Sci. $26,223-233$.

Bracone, V., Amorosi, A., Aucelli, P.P.C., Rosskopf, C.M., Scarciglia, F., Di Donato, V., Esposito, P., 2012. The Pleistocene tectono-sedimentary evolution of the Apenninic foreland basin between Trigno and Fortore rivers (Southern Italy) through a se- quence-stratigraphic perspective. Basin Res. 24, 213-233. https://doi.org/10.1111/j. 13652117.2011.00523.x.

Bresciani, I., Perotti, C.R., 2014. An active deformation structure in the Po Plain (N. Italy): the Romanengo anticline. Tectonics. https://doi.org/10.1002/2013TC003422. $(\mathrm{n} / \mathrm{a}-\mathrm{n} / \mathrm{a})$.

Brewer, R., 1964. Fabric and Mineral Analysis of Soils. John Wiley and Sons, New York. Bridge, J.S., 2003. Rivers and Floodplains: Forms, Processes and Sedimentary Record. Blackwell, Oxford, UK.

Bruno, L., Amorosi, A., Severi, P., Costagli, B., 2017. Late Quaternary aggradation rates and stratigraphic architecture of the southern Po Plain, Italy. Basin Res. 29, 234-248. https://doi.org/10.1111/bre.12174.

Bullock, P., Fedoroff, N., Jongerius, A., Stoops, G., Tursina, T., Babel, U., 1985. Handbook for Soil Thin Section Description. Waine Research Publications, Wolverhampton. Buntley, G., Westin, F., 1965. A comparative study of developmental color in a Chestnut- Chernozem-Brunizem soil climosequence. Soil Sci. Soc. Am. J. $29,579-582$.

Burrato, P., Ciucci, F., Valensise, G., 2003. An inventory of river anomalies in the Po Plain, Northern Italy: evidence for active blind thrust faulting. Ann. Geophys. 46, 865882.

Burrato, P., Vannoli, P., Fracassi, U., Basili, R., Valensise, G., 2012. Is blind faulting truly invisible? Tectonic-controlled drainage evolution in the epicentral area of the May 2012, Emilia-Romagna earthquake sequence (northern Italy). Ann. Geophys. https:// doi.org/10.4401/ag-6182.

Busacca, A., Cremaschi, M., 1998. The role of time versus climate in the formation of deep soils of the Apennine fringe of the Po Valley, Italy. Quat. Int. 51, 95-107.

Castiglioni, G.B., Pellegrini, G.B., 2001. Note illustrative della Carta Geomorfologica della Pianura Padana. Suppl. di Geogr. Fis. e Din. Quat. vol. IV.

Catt, J.A., 1989. Relict properties in soils of the central and north-west European tem- perate region. Catena Suppl. 16, 41-58.

Catt, J.A., 1998. Report from working group on definitions used in Paleopedology. Quat. Int. 84. https://doi.org/10.1016/S1040-6182(98)90232-4. 
Coltorti, M., Pieruccini, P., 2000. A late Lower Pliocene planation surface across the Italian Peninsula: a key tool in neotectonic studies. J. Geodyn. 29, 323-328. https:// doi.org/10.1016/S0264-3707(99)00049-6.

Cordova, C., 2000. Geomorphological evidence of intense prehistoric soil erosion in the highlands of Central Jordan. Phys. Geogr. 21, 538-567.

Costantini, E.A.C., 2017. Paleosols and pedostratigraphy. Appl. Soil Ecol. 1-4. https:// doi.org/10.1016/j.apsoil.2017.09.021.

Costantini, E.A., Fantappié, M., L'Abate, G., 2013. Climate and Pedoclimate of Italy. In: The Soils of Italy. Springer, Netherlands, pp. 19-38. https://doi.org/10.1007/978- 94007-5642-7.

Cremaschi, M., 1987. Paleosols and Vetusols in the Central Po Plain (Northern Italy): A Study in Quaternary Geology and Soil Development. UNICOPLI, Milano.

Cremaschi, M., 2004. Late pleistocene loess. In: Antonioli, F., Vai, G.B. (Eds.), Litho- Palaeoenvironmental Maps of Italy during the Last Two Climatic Extremes. Climex Maps Italy - Explanatory Notes, pp. 34-37 (Bologna).

Cremaschi, M., Rodolfi, G., 1991. Il suolo. Pedologia nelle scienze della terra e nella valutazione del territorio. La Nuova Italia Scientifica, Roma.

Cremaschi, M., Zerboni, A., Nicosia, C., Negrino, F., Rodnight, H., Spötl, C., 2015. Age, soil-forming processes, and archaeology of the loess deposits at the Apennine margin of the Po plain (northern Italy): new insights from the Ghiardo area. Quat. Int. 376, 173-188. https://doi.org/10.1016/j.quaint.2014.07.044.

D'Agostino, N., Avallone, A., Cheloni, D., D'Anastasio, E., Mantenuto, S., Selvaggi, G., 2008. Active tectonics of the Adriatic region from GPS and earthquake slip vectors. J. Geophys. Res. Solid Earth 113, 1-19. https://doi.org/10.1029/2008JB005860.

Desio, A., 1965. I rilievi isolati della Pianura Lombarda ed i movimenti tettonici del Quaternario. Rend. dell'Istituto Lomb. di Sci. e Lett. A. pp. 881-894.

Devoti, R., Esposito, A., Pietrantonio, G., Pisani, A.R., Riguzzi, F., 2011. Evidence of large scale deformation patterns from GPS data in the Italian subduction boundary. Earth Planet. Sci. Lett. 311, 230-241. https://doi.org/10.1016/j.epsl.2011.09.034.

Duchaufour, P., 1995. Pédologie. Sol, végétation, environnement. (Masson, Paris). Erhart, H., 1967. La genèse des sols en tant que phénomène géologique. (Masson, Paris). ERSAL, 2000. I suoli del lodigiano. (Milano).

ERSAL, 2001a. I suoli della pianura pavese centrale. (Milano).

ERSAL, 2001b. Carta dei pedopaesaggi della Lombardia - 1:250,000. S.EL.CA.,Firenze. ERSAL, 2002. I suoli del codognese. (Milano).

ERSAL, 2013. Carta dei suoli in scala 1:50.000 della pianura e collina lombarda.

Fantoni, R., Bersezio, R., Forcella, F., 2004. Alpine structure and deformation chronology at the Southern Alps-Po Plain border in Lombardy. Boll. Soc. Geol. Ital. 123, 463476.

FAO, 2006. Guidelines for Soil Description. Food and Agriculture Organization of the United Nations, Rome.

Fedoroff, N., Courty, M.-A., 2012. Textural features and microfacies expressing temporary and permanent soil water saturation. In: Proceedings of the 14th International Working Meeting on Soil Micromorphology, pp. 3-6 (Lleida).

Ferraro, F., 2009. Age, sedimentation, and soil formation in the Val Sorda loess sequence, Northern Italy. Quat. Int. 204, 54-64. https://doi.org/10.1016/j.quaint.2008.12. 002

Frigerio, C., Bonadeo, L., Zerboni, A., Livio, F., Ferrario, M.F., Fioraso, G., Irace, A., Brunamonte, F., Michetti, A.M., 2017. First evidence for Late Pleistocene to Holocene earthquake surface faulting in the Eastern Monferrato Arc (Northern Italy): geology, pedostratigraphy and structural study of the Pecetto di Valenza site. Quat. Int. 451, 143-164. https://doi.org/10.1016/j.quaint.2016.12.022.

Gale, S., Hoare, P., 1991. Quaternary Sediments. Belhaven Press, London.

Ghielmi, M., Minervini, M., Nini, C., Rogledi, S., Rossi, M., 2013. Late Miocene-Middle Pleistocene sequences in the Po Plain-Northern Adriatic Sea (Italy): the stratigraphic record of modification phases affecting a complex foreland basin. Mar. Pet. Geol. 42, 50-81. https://doi.org/10.1016/j.marpetgeo.2012.11.007.

Heinz, J., Aigner, T., 2003. Hierarchical dynamic stratigraphy in various Quaternary gravel deposits, Rhine glacier area (SW Germany): implications for hydrostratigraphy. Int. J. Earth Sci. 92, 923-938. https://doi.org/10.1007/s00531-003- 0359-2.

Holbrook, J., Schumm, S.A., 1999. Geomorphic and sedimentary response of rivers to tectonic deformation: a brief review and critique of a tool for recognizing subtle epeirogenic deformation in modern and ancient settings. Tectonophysics 305, 287-306. https://doi.org/10.1016/S0040-1951(99)00011-6.

INQUA WG, 1995. Definitions used in Paleopedology. Paleopedol. Gloss. 11 (2). INQUA/ ISSS Paleopedology Commission, Newsletter, pp. 35-37.

Kemp, R.A., 1999. Micromorphology of loess-paleosol sequences: a record of pa- leoenvironmental change. Catena 35, 179-196. https://doi.org/10.1016/S03418162(98)00099-X.

Kemp, R.A., 2001. Pedogenic modification of loess: significance for paleoclimatic re- constructions.pdf. Earth Sci. Rev. 54, 145-156.

Kubiëna, W.L., 1953. Bestimmungsbuch und Systematik der Böden Europas. Ferdinand Enke Verlag.

Kühn, P., Terhorst, B., Ottner, F., 2006. Micromorphology of middle Pleistocene pa- laeosols in northern Italy. Quat. Int. 156-157, 156-166. https://doi.org/10.1016/j. quaint.2006.05.026.

Lisiecki, L.E., Raymo, M.E., 2005. A Pliocene-Pleistocene stack of 57 globally distributed benthic $\delta^{18}$ O records. Paleoceanography 20. https://doi.org/10.1029/2004PA001071.

Livio, F., Berlusconi, A., Michetti, A.M., Sileo, G., Zerboni, A., Trombino, L., Cremaschi, M., Mueller, K, Vittori, E., Carcano, C., Rogledi, S., 2009, Active fault-related folding in the epicentral area of the December 25, 1222 (Io = IX MCS) Brescia earthquake (Northern Italy): seismotectonic implications. Tectonophysics 476, 320-335. https:// doi.org/10.1016/j.tecto.2009.03.019.

Livio, F., Berlusconi, A., Zerboni, A., Trombino, L., Sileo, G., Michetti, A.M., Spotl, C., Rodnight, H., 2012. Active fold growth constrained by a Loess-Paleosols Sequence (Monte Netto, Southern Alps). Rend. Online Soc. Geol. Ital. 22, 126-129.

Livio, F.A., Berlusconi, A., Zerboni, A., Trombino, L., Sileo, G., Michetti, A.M., Rodnight, H., Spotl, C., 2014. Progressive offset and surface deformation along a seismogenic blind thrust in the Po Plain foredeep (Southern Alps, Northern Italy). J. Geophys. Res. Solid Earth 1482-1497. https://doi.org/10.1002/2013JB010193. (Received)

Lucke, B., Sprafke, T., 2015. Correlation of Soil Color, Redness Ratings, and Weathering Indices of Terrae Calcis Along a Precipitation Gradient in northern Jordan. Erlanger Geogr. Arb. Band. 42. pp. 53-68.

Maesano, F.E., D'Ambrogi, C., 2016. Coupling sedimentation and tectonic control: Pleistocene evolution of the central Po Basin. Ital. J. Geosci. 135, 394-407. https:// doi.org/10.3301/IJG.2015.17.

Maesano, F.E., D'Ambrogi, C., Burrato, P., Toscani, G., 2015. Slip-rates of blind thrusts in slow deforming areas: examples from the Po Plain (Italy). Tectonophysics 643, 8-25. https://doi.org/10.1016/j.tecto.2014.12.007.

Maestrelli, D., Benvenuti, M., Bonini, M., Carnicelli, S., Piccardi, L., Sani, F., 2018. The structural hinge of a chain-foreland basin: Quaternary activity of the Pede-Apennine Thrust front (Northern Italy). Tectonophysics 723, 117-135. https://doi.org/10. 1016/j.tecto.2017.12.006.

Martini, M., Sibilia, E., Croci, S., Cremaschi, M., 2001. Thermoluminescence (TL) dating of burnt flints: problems, perspectives and some examples of application. J. Cult. Herit. 2, 179-190. https://doi.org/10.1016/S1296-2074(01)01126-8.

Martinson, D.G., Pisias, N.G., Hays, J.D., Imbrie, J., Moore, T.C., Shackleton, N.J., 1987. Age dating and the orbital theory of the ice ages: development of a high resolution 0 to 300,000 year chronostratigraphy. Quat. Res. 27, 1-29. https://doi.org/10.1016/ 0033-5894(87)90046-9.

Mc Carthy, P.J., Plint, A.G., 2003. Spatial variability of palaeosols across Cretaceous in- terfluves in the Dunvegan Formation, NE British Columbia, Canada: palaeohydrological, palaeogeomorphological and stratigraphic implications. Sedimentology 50, 1187-1220. https://doi.org/10.1111/j.1365-3091.2003.00600.x.

Mc Rae, S., 1991. Pedologia pratica: come studiare i suoli sul campo. Zanichelli, Bologna.

Miall, A.D., 1996. The Geology of Fluvial Deposits: Sedimentary Facies, Basin Analysis and Petroleum Geology. Springer-Verlag, Heidelberg.

Ministero delle Politiche Agricole e Forestali, 2000. Metodi di analisi chimica del suolo. Franco Angeli Editore, Milano.

Ministero per le Politiche Agricole, 1999. Metodi ufficiali di analisi fisica del suolo. D.M. del 13 settembre 1999. Gazz. Uff. Suppl. Ordin. n. 248 del 21.10.99.

Morelli, A., Bruno, L., Cleveland, D.M., Drexler, T.M., Amorosi, A., 2017. Reconstructing Last Glacial Maximum and Younger Dryas paleolandscapes through subsurface pa- leosol stratigraphy: an example from the Po coastal plain, Italy. Geomorphology 295, 790-800. https://doi.org/10.1016/j.geomorph.2017.08.013.

Mroczek, P., 2013. Recycled loesses - a micromorphological approach to the determina- tion of local source areas of Weichselian loess. Quat. Int. 296, 241-250. https://doi. org/10.1016/j.quaint.2013.02.040.

Munsell®, 1994. Soil color charts. rev. Munsell®, New Windsor.

Murphy, C.P., 1986. Thin Section Preparation for Soils and Sediments. A. B. Academic Publishers, Berkhamsted.

Ori, G.G., 1993. Continental depositional system of the Quaternary of the Po Plain (northern Italy). Sediment. Geol. 83, 1-14.

Panzeri, L., Zembo, I., Bersezio, R., Martini, M., 2011. Calibration of OSL data: mismatch between stratigraphy and OSL chronology pf sediments from the Po Plain. Quaternario 24, 114-116. 
Pellegrini, L., Boni, P., Carton, A., 2003. Hydrographic evolution in relation to neotec- tonics aided by data processing and assessment: some examples from the Northern Apennines (Italy). Quat. Int. 101-102, 211-217. https://doi.org/10.1016/S1040- 6182(02)00103-9.

Pieri, M., Groppi, G., 1981. Subsurface Geological Structure of the Po Plain, Italy, in: Progetto Finalizzato Geodinamica. CNR, Progetto Finalizzato Geodinamica, pp. 13.

Pini, R., Ravazzi, C., Donegana, M., 2009. Pollen stratigraphy, vegetation and climate history of the last 215 ka in the Azzano Decimo core (plain of Friuli, north-eastern Italy). Quat. Sci. Rev. 28, 1268-1290. https://doi.org/10.1016/j.quascirev.2008.12. 017.

Pye, K., 1995. The nature, origin and accumulation of loess. Quat. Sci. Rev. 14, 653-667. https://doi.org/10.1016/0277-3791(95)00047-X.

Ravazzi, C., Deaddis, M., De Amicis, M., Marchetti, M., Vezzoli, G., Zanchi, A., 2012. The last 40 ka evolution of the Central Po Plain between the Adda and Serio rivers. Geomorphol. Relief Process. Environ. 131-154.

Reading, H.G., 1996. Sedimentary Environments: Processes, Facies and Stratigraphy, 3rd ed. Blackwell Publishing.

Regione Lombardia, Eni Divisione Agip, 2001. Geologia degli acquiferi padani della Regione Lombardia. S.EL.CA., Firenze, Italy. https://doi.org/10.1017/ CBO9781107415324.004.

Reimer, P.J., Edouard Bard, B., Alex Bayliss, B., Warren Beck, B.J., Paul Blackwell, B.G., Christopher Bronk Ramsey, B., 2013. Intcal13 and Marine13 radiocarbon age calibration curves 0-50,000 years Cal BP. Radiocarbon 55, 1869-1887.

Rhodes, E.R., Sutton, P.N., 1978. Active iron ratio of some soils from three physiographic units in Sierra Leone. Soil Sci. 125, 326-328.

Schwertmann, U., 1964. Differenzierung der Eisenoxide des Bodens durch Extraktion mit Ammoniumoxalat-Lösung. J. Plant Nutr. Soil Sci. 105, 194-202.

Scrocca, D., Carminati, E., Doglioni, C., Marcantoni, D., 2007. Slab retreat and active shortening along the central-northern Apennines. In: Lacombe, O., Lave', J., Roure, F., Verges, J. (Eds.), Thrust Belts and Foreland Basin: From Fold Kinematics to Hydrocarbon Systems. Springer, New York, pp. $471-487$.

Shackleton, N.J., 1987. Oxygen isotopes, ice volume and sea level. Quat. Sci. Rev. 6, 183-190. https://doi.org/10.1016/0277-3791(87)90003-5.

Soil Survey Staff, 2014. Keys to soil taxonomy. Soil Conserv. Serv. 12, 410. https://doi. org/10.1109/TIP.2005.854494.

Srivastava, P., Rajak, M.K., Singh, L.P., 2009. Late Quaternary alluvial fans and paleosols of the Kangra basin, NW Himalaya: tectonic and paleoclimatic implications. Catena 76, 135-154. https://doi.org/10.1016/j.catena.2008.10.004.

Stoops, G., 2003. Guidelines for Analysis and Description of Soil and Regolith Thin Sections. Soil Science Society of America, Madison WI.

Stoops, G., Marcelino, V., Mees, F., 2010. Interpretation of Micromorphological Features of Soils and Regoliths. Elsevier, Oxford, UK.

Terhorst, B., Ottner, F., 2003. Polycyclic luvisols in Northern Italy: Palaeopedological and clay mineralogical characteristics. Quat. Int. 106-107, 215-231. https://doi.org/10. 1016/S1040-6182(02)00174-X.

Toscani, G., Seno, S., Fantoni, R., Rogledi, S., 2006. Geometry and timing of deformation inside a structural arc: the case of the western Emilian folds (Northern Apennine front, Italy). Boll. Soc. Geol. Ital. 125, 59-65.

USDA, 1999. Soil Taxonomy. A Basic System of Soil Classification for Marking and Interpreting Soil Surveys. U.S. Government Printing Office, Washington. https://doi. org/10.1017/S0016756800045489.

Valle, G., 1984. Appendice I alle note illustrative del Piano Provinciale cave di Pavia - schede descrittive dei ritrovamenti archeologici. Piano Cave Prov. di Pavia.

Varga, A., Újvári, G., Raucsik, B., 2011. Tectonic versus climatic control on the evolution of a loess-paleosol sequence at Beremend, Hungary: an integrated approach based on paleoecological, clay mineralogical, and geochemical data. Quat. Int. 240, 71-86. https://doi.org/10.1016/j.quaint.2010.10.032.

Walkley, A., Black, I., 1934. An examination of the Degtjareff method for determining soil organic matter, and a proposed modification of the chromic acid titration method. Soil Sci. 37, 29-38

Weber, K.J., 1986. How heterogeneity affects oil recovery. In: Lake, L.W., Carrol, H.B.J. (Eds.), Reservoir Characterization. Academic Press, Inc., pp. 487-544.

Wick, L., 1996. Late-glacial and early-Holocene palaeoenvironments in Brianza, N Italy. Quaternario 9, 653-660

WRB IUSS Working Group, 2015. World Reference Base for Soil Resources 2014, Update 2015 International Soil Classification System for Naming Soils and Creating Legends for Soil Maps, World Soil Resources Reports. FAO, Rome.

Zembo, I., Trombino, L., Bersezio, R., Felletti, F., Dapiaggi, M., 2012. Climatic and tec- tonic controls on pedogenesis and landscape evolution in a Quaternary Intramontane Basin (Val D'Agri Basin, Southern Apennines, Italy). J. Sediment. Res. 82, 283-309. https://doi.org/10.2110/jsr.2012.22.

Zerboni, A., Trombino, L., Frigerio, C., Livio, F., Berlusconi, A., Michetti, A.M., Rodnight, H., Spotl, C., 2014. The loess-paleosol sequence at Monte Netto: a record of climate change in the Upper Pleistocene of the central Po Plain, northern Italy. J. Soils Sediments 15, 1329-1350. https://doi.org/10.1007/s11368-014-0932-2.

Zuccoli, L., 1997. Geologia dell'Alta Pianura Lombarda tra i Pianalti di Castelseprio e Tradate-Appiano Gentile. Università degli Studi di Milano.

Zuffetti, C., Bersezio, R., Contini, D., Petrizzo, M.R., Trombino, L., 2017. Quaternary evolution of the Central Po Plain: surface constraints from the San Colombano relief (Lombardy, Italy). J. Mediterr. Earth Sci. 9, 209. https://doi.org/10.3304/JMES 2017.004.

Zuffetti, C., Bersezio, R., Contini, D., Petrizzo, M.R., 2018. Geology of the San Colombano hill, a Quaternary isolated tectonic relief in the Po Plain of Lombardy (Northern Italy). J. Maps 14, 199-211. https://doi.org/10.1080/17445647.2018.1443166. 